\title{
6 CASE TWO: Reversals of Body-Law in Norway: Birth Control and Abortion
}

\subsection{Introduction: Same Issues, Different Direction, Different Result}

Both the United States and Norway underwent social movements that advocated for the right to birth control and to have an abortion within certain parameters; but those paths took different forms and eventually led to significant differences. Effectively, the Storting became the arena in which the debate on these measures took place in Norway. In America, reformers worked at both the state and federal levels within their individual state legislatures, all the while attempting various arguments at the Supreme Court level. In contrast to the American case law resulting from the facts in Griswold v. Connecticut, 381 U.S. 479 (1965), the Norwegian Storting had, at various times, passed laws on birth control and abortion from the late 1950s to 1978, in which accommodations on the issues had been reached and legally formalized within that body. But in 1978, the new Norwegian law was the result of a legislative consensus which itself was based on a larger socio-political upheaval. Norwegian women had tried for as long as their country had existed to extract the same reproductive rights as their American counterparts had also fought for, working consistently but also unsuccessfully on the other side of the Atlantic Ocean.

At the beginning of the Storting session in 1978, members of the Norwegian Storting who might have happened to read Aftenposten, could have read about protests by both the Christian-based Folkesaksjon (People's Action Against Abortion, FASA) and the Feminist Movement in Oslo and throughout Norway. ${ }^{914}$ Segments of the national Lutheran Church (Den Norske Kirke, DNK) in Norway became the leading resisters to social change especially change with regard to the role of women in society and to any changes in sexual norms. The consensus that was eventually reached in the Storting was a difficult one and will be examined here as well as the politics and social movements surrounding the change in the law and the various social schemas and structures brought into play in the process.

The legal right to possess methods for birth control by women and to secure abortion rights in Norway was actualized incrementally, ending, for the purpose of this analysis, in 1978 in a new abortion law. As in the United States, the same two debates took place in stages alongside one another. In both cases, the right to birth control was perhaps more visible than the right to an abortion, although the two

914 For example, please see Aftenposten (p.m. edition), 19 January 1978, p. 1) and Aftenposten (p.m.) 8 March 8, 1978, 1 and continued throughout the year. Please see, Aftenposten (a.m. edition), 16 October 16, 1978, 3 and Aftenposten (p.m. edition), November 2, 1978, 7. 
issues were joined - by necessity. The most proximate attempt to the new 1978 law to allow abortion had been introduced into the Norwegian Parliament during its 1974 session and had been voted down on 31 October 1974 by the non-socialist parties along with one SV Representative, Otto Hauglin. The result was an abortion law, passed on 13 June 1975, which would come into full force and effect on 1 January 1976. A year earlier, the Norwegian abortion law had been enacted, on 13 June 1975 and entitled Law on abortion No. 50; it superseded a law passed on 11 November 1960, nr. 1. which itself had changed the 1902 Criminal Law provision for punishment of abortion. ${ }^{915}$ The 1975 law had allowed for abortion if a woman's pregnancy would lead to "an unreasonable or unfair physical or psychological burden for the woman" or put her in a "difficult life situation."916 It was perceived as a serious setback to Norwegian women and their vision of self-decided abortion. It was not only considered unacceptable to progressive women but this law was considered to be unacceptable to all parties involved.

Women regrouped and launched another campaign, beginning with abortion hearings in the Parliament in 1976 and a women's political action movement in 1977. The goal of this action was to increase birth control information including easier access to it. The goal was, eventually, to force Storting representatives to pass another abortion law that allowed for "self-decided" abortion within the first 12 weeks of pregnancy. These demands were finally met and a new abortion law including these criteria was passed on 9 June 1978, after more than 65 years of political pressure, agitation and political maneuvering by Norwegian women. ${ }^{917}$

In both countries the debate over birth control and abortion took place in conjunction with a number of other issues; these included such things as a woman's right to work and to equal pay for equal work. But what is unique in the comparison between these two countries in this second case study is that Norwegian women - and men - obtained a gender equality law. The Norwegian Storting also passed the Lov om likestilling mellom kjønnene (Law on the equality of the sexes, No. 45 on 9 June 1978. (LLK) The act was actively supported by the Labour Party and the Socialist Left Party and was primarily meant to address inequality that women faced in their working life. Section 1 of the law states:

915 Hans Flock, Birger Stuevold Lassen, Henrik Bull, Anne-Marie Tronslin, eds., Norges Lover, 16872003, (Oslo: Utgitt av Det Juridiske Fakultet ved Universitetet i Oslo, 2004), 67, 1008. The 1978 law was not the first time the abortion law in Norway had been changed by legislation; it had been changed in 1964. However, for the purposes of this dissertation I will concentrate on the 1978 law.

916 Ibid., 285.

917 Please see, for example, Elizabeth Lønnå, Stolhet og Kvinnekamp: Norsk Kvinnesaksforenings historie fra 1913 (Oslo: Glydendal Norsk Forlag, 1996). 
This law shall concern equality between both sexes and is especially concerned with bettering the position of women. Women and men shall be given equal opportunities to education, work, and cultural and professional development." ${ }^{18}$

This language clearly envisions that some, if not a large role, be played by the law rather than through using some vague notion of "good will" within the workplace as a method for mandating equality. ${ }^{919}$ Given that the law mentions equal opportunity in education, work, cultural and professional development, emphasis has been extended to these areas. ${ }^{920}$ Particularly important was the establishment of oversight and enforcement bodies such as the Lov om likestilling mellom kjønnene (§§ 10-12), provided for in the 1978 Law. ${ }^{921}$

Again, in 1981, three years after the gender equality law was passed, the Parliament made another bold move, especially in comparison with the United States, and the gender equality act was amended to include a new provision, $\$ 21 .{ }^{922}$ This section required a $40 \%$ representation of both sexes on all public boards, councils and committees. The intent of was to urge women from traditional female centers of influence such as health to enter the political realm and to increase their representation in what were traditional male strongholds such as defense, technology, agriculture and communications. This "Forty Per Cent Rule" was also incorporated into the Local Government Act of $1992 .{ }^{923}$ By contrast, the issue of an ERA in the United States has become dormant. ${ }^{224}$

918 Flock, Lassen, Bull, Tronslin (eds.), Norges Lover, 1687-2003, 1085. Note 831.

919 That Norway has had a long history of a vigorous labor movement should be noted. Women were a part of this movement and had a great deal of experience with the "carrot and stick" approach to solving workplace problems. While the United States also had a labor movement, it seems it might not have had the momentum or a class-based consciousness that prevailed into the middle half of the $20^{\text {th }}$ century. Norway had this momentum.

920 Some exemptions exist, e.g. for religious communities.

921 The Act is also enforced by the Equal Status Council, founded in 1972, as stipulated in law nr. 47 of 1972; both provisions are responsible for organizations that serve as a liaison with authorities, organizations and the public on matters of equality under the act. The Lov om likestilling mellom kزønnene of 9 June. No. 491978 can be found in Norges Lover at pages 1085-1089. §§10 and 11 were amended in 2003.

922 Ibid. Law nr. 59 of 1981. The 1978 law has been amended several times, including by nr. 12/1983, nr. 6/1988, and nr. 120/2003. The gender law must adapt to laws with which it interacts when these laws have been modified. The 1981 revision extends the reach of the law to elected and appointed political bodies.

923 The " $40 \%$ Rule" requires that the balance of the two sexes in governmental positions, as outlined by law, must have a ratio between 40:60 (females: males) and 60:40.

924 In 1977, Indiana was the last state, the $35^{\text {th }}$ of the needed 38 states to ratify the ERA. Each year it is reintroduced in Congress and the deadline for ratification has been extended at least once. To be passed, it needs three more states to ratify it and, at this point, the prospects of any three more states ratifying it are slim. This "bootstrap" philosophy combined with an other factors makes it unlikely any ERA will be successful in the United States until or unless some situation forces a reexamination 
Before considering specific norms, actors, structures and events at work in 1978 in Norway, we need to examine how life had changed in Norway between 1934 and 1978; this includes a brief look at social schemas, demographics and the role of DNK. In 1956, the Norwegian Program for Electoral Research, which had been established at the Institute for Social Research in Oslo by Stein Rokkan and Henry Valen, collected data about Norwegian voters. ${ }^{925}$ The representative sample was of voters between the ages of 20 and 80 years of age and was still being evaluated by researchers a decade later, including W. Martinussen. This year - 1956 - is exactly midway between 1934 and 1978 and I use the data from it as a means of giving some idea of the social currents moving within Norwegian society 22 years before the abortion and equality laws were passed.

By 1978, Norway was again experiencing a socio-political "crisis" much as it had in 1934, although in 1978, the economic life of most citizens was certainly better. My use of the word "crisis" here is meant to imply that an imbalance in societal relations makes stasis nearly impossible, i.e. that some sort of change may be imminent, and this seems to exactly be the case. As I noted above, Martinussen studied the Rokkan/ Valen data, focusing on a significant question, i.e. could one "detect a decreasing effect of the sex role norms and sex discrimination" or, were those norms and discrimination "just as powerful today as they were in previous generations?"926 To answer this, he analyzed political alienation as it is related to sex, age and education. As a general rule, differences between men and women in political alienation were "greatest in the younger age groups" and these differences decrease with age, perhaps as result of marriage, which tended to increase security for a woman. ${ }^{927}$

Martinussen found that women were "to a certain extent" more politically powerless and indifferent than men but were not particularly more detached from the political process." ${ }^{928}$ He concluded that the higher a woman's education and the more politically relevant her organizational membership, the less a woman might label her experience as politically alienating. This was true, of course, for men as well as women at this time. But Martinussen also found that "sex differences are still extensive" and could be summarized as follows:

1. Women are to a certain extent more politically indifferent and powerless than men within the categories where they are equal with men with regard to education and degree of political organization. The exceptions to this general trend are insignificant, but we note that for the politically organized with primary school or less, both men and women are of 'average' indifference, and among the experts

of priorities and institutions.

925 Willy Martinussen, The Distant Democracy: Social inequality, political resources and political influence in Norway (London and New York: John Wiley \& Sons, 1977), 14, ii.

926 Ibid., 164.

927 Ibid.

928 Ibid., 161. 
who are nonpolitically organized, the men are insignificantly more powerful than women. ${ }^{929}$

2. Women are more subjectively detached from politics than men in the group 'politically organized with a low level of education', while the opposite is the case among the nonpolitically organized: women more than men believe that politics affect their everyday life. This standpoint is most often taken by politically organized experts of both sexes.

3. Politically organized women at the two lowest levels of education are more suspicious of the political parties than men, and those with the lowest level of education have the least confidence in the conduct of the public authorities. ${ }^{930}$

The opposite situation was to be found among those who were not members of unions; to a greater extent, more men than women believed that authorities practiced discrimination.

How did political alienation relate to party affiliation? Martinussen relied on responses by those who had voted in the 1969 Parliamentary election and looked at three factors - the lack of opportunity, the lack of motivation and the lack of political participation experiences - with relation to political affiliation. A few simple conclusions can be noted here which help to highlight how the 1978 abortion legislation came into being. Across the political spectrum in 1969, from the extreme political left (Communist) to the extreme political right (Conservatives), the highest percentage, with regard to a lack of motivation as measured by "indifference" rested in the Agrarian party. The perception of "powerlessness" was highest in the Labour Party and "detachment" was highest - again - in the Agrarian Party followed closely by the Christian People's Party. The least detached were members of the Communist Party, followed by four parties at essentially the same level, the Social Democratic Party, the Labour Party, the Liberal and Conservative Party. Those who felt the least powerless were in the Christian People's Party, followed by the Conservatives and the Social Democratic Party. By occupation, the same study found that fishermen, followed by manual workers experienced the most political poverty. ${ }^{931}$ Those with the least political poverty were high ranking public officials followed by high-ranking private executives.

Based on these conclusions, the nine years from 1969 to 1978 were nothing short of turbulent - especially with regard to the issue of gender and political alienation. The perception of sex discrimination was prominent among younger people, especially women. If we look at the group of 20 to 30 year old citizens, who would be in the

929 Ibid. The three levels of organization were politically organized, non-politically organized and not organized.

930 Ibid., 161-62. The three levels of education investigated were primary education, vocational education and professional education.

931 Ibid., 204. Table 9.5. 
30 to 40 year group ten years later in 1978, we find the following differences between men and women. (In bold lettering below.)

Table 6.1: Political alienation related to sex in specific age group ${ }^{932}$

\begin{tabular}{lllllll}
\hline $\begin{array}{l}\text { Women and Men, } \\
\text { 20-30 Years of Age in 1969 }\end{array}$ & Primary Education & Vocational & & Professional \\
\hline Form of political alienation & Women & Men & Women & Men & Women & Men \\
Indifference & 72 & 46 & 66 & 38 & 36 & 18 \\
Powerlessness & 78 & 70 & 70 & 47 & 26 & 38 \\
Detachment & 50 & 46 & 51 & 44 & 32 & 45 \\
Distrust of parties & 75 & 54 & 62 & 57 & 48 & 64 \\
Belief in discrimination & 55 & 36 & 90 & 80 & 46 & 63 \\
Average $N=$ & 13 & 13 & 90 & 80 & 30 & 40 \\
\hline
\end{tabular}

The above table is but one small piece of the 1969 survey mentioned above done by the Institute for Social Research in Oslo. But, from this table we can see that, assuming little change, an engine that drove socio-cultural changes in the decade prior to 1978 could be related to the discrimination that women who had a vocational education felt as well as the feelings of both men and women who had a professional education. It is difficult to argue with these numbers; clearly there was a feeling that discrimination based on sex was present in Norway. While professionally educated men and women felt less powerless and were less indifferent than the other two groups, both men and women in the other two groups, with the possible exception of men with a primary education, could have supported the women in their views on discrimination. But this sense of unfairness was not the only force at work. As we will see, the decrease in DNK attendance, i.e. religiosity, also played a major role in both the abortion and sexual equality laws that were passed in 1978.

The table also shows that feelings of indifference, powerlessness, detachment and distrust of parties ran across the spectrum of differing levels of education. This, in combination with how the degrees to which different major political parties felt "powerless" lends credibility to the idea of a social crisis in the making or already in place. ${ }^{933}$ As we saw above, the KrF felt the most powerful while Ap felt the least powerful. But KrF also felt more "detached" than a combination of the Labour Party along with Liberals and Conservatives. KrF's detachment is seen in full bloom 10 years later during the abortion debate in its ideologically directed debate. The sense of "powerful" that the KrF felt was realized when the Ap lost the 1969 election. However, at

932 Ibid., 165. This Table is extracted information for the 20-30 year old group. The original 3 tables on page 165 also had figures for 31-50 years of age and 51-80 years of age.

933 See Lønnå, Stolthet og kvinnekamp, 223. Note 1106. Lønna calls the year 1968 the "quiet before the storm.” My thanks to Ellen Andenæs for bringing this book to my attention. 
the Ap's national convention in 1969, it endorsed self-decided abortion for women and did not withdraw from that position until, after other parties joined, the law was changed in 1978..$^{934}$

Martinussen argues that five factors play a role in the extent to which citizens do nor do not seek political change. These are that, 1. individuals and groups who have unequal access to "values", and therefore it is possible to speak of inequality of conditions in which people live, 2. these inequalities are socially recognized and citizens believe themselves to have a common interest with people in similar groups, 3. the inequality of circumstances and recognition of this create differences in political beliefs and orientations as well as in attitudes toward the then current political system, 4. the inequality of circumstances means systematic differences in access to material, social and intellectual political resources, and 5. the differences in access to political resources and political motivation leads to inequality of actual political participation. ${ }^{935}$ Given these five factors, we could say that there was a crisis looming on the horizon for Norway in the decade following 1959 when this research data was collected.

During 1978, statistics about various intersubjective groups ${ }^{936}$ and about families in Norway were seen in the pages of a number of papers, including Aftenposten. Statisk Sentralbyrå (The Central Bureau for Statistics, SSB) in Norway had published a report in July of 1977 with statistics on family life in Norway. Norway had approximately 1,630,000 families as of that date. Of this number, 39\% or 633,000 married couples were living with children in the home while $19 \%$ or 306,000 married couples did not have children living with them. Seven per cent of the 1.63 million families, or 116,000 families, consisted of a mother or a father, but not both, as heading the household. ${ }^{937}$ The remaining 35\% were living alone - 15\% men and $21 \%$ women. ${ }^{938}$

In addition to relying on newspaper data, we can turn to the area of Fertility Studies which has recently given us a more complete idea of what was happening in Europe in the years leading up to the industrial revolution and the development of the

934 Ibid., p. 242.

935 Martinussen, The Distant Democracy, 12. Note 1114.

936 Noteworthy are those differently abled and the mentally ill, especially at Trondheim's facility, Reitgårdet.

937 Aftenposten (p.m. Edition), 3 March 1978, 6.

$938 \mathrm{Ibid}$. Three definitions of a family were given. There were, 1. one which must be registered as living in the same house and consisting of a man and hustru (housewife) with or without unmarried children, or 2. either a mother or a father with unmarried children, or 3. a single person, regtistered as living in a house, living without unmarried children and without a spouse or a parent. (Familienenheten er definert some en ren familiekjerne, og personene innenfor en famliekjerne må være registrert bosatt i sammen bolig. En familile kan bestå av mann og hustru uten eller med ugifte barn, mor eller far med ugifte barn, eller enslig person some er registrert bosatt uten ugifte barn og ikke sammen men ektefelle eller foreldre.) 
birth control pill. Two different types of demographic studies have given us a picture of Europe; they are micro-level family reconstitution studies and macro-level studies based on published census and geographically defined vital statistics. ${ }^{939}$ Knodel and van de Walle make four observations of marital fertility between 1800 and 1970,940 keeping in mind that nuptuality patterns in Western Europe played a key role in preindustrial Europe as opposed, for example, to developing countries today. These four conclusions are:

4. Fertility declines took place under a variety of social, economic and demographic conditions.

5. The practice of family limitation was largely absent (and probably unknown) among broad segments of the population prior to the decline on fertility, even though a substantial proportion of births may have been unwanted.

6. Increases in the practice of family limitation and the decline of marital fertility were essentially irreversible processes once underway.

7. Cultural setting influences the onset and spread of fertility decline independently of socioeconomic conditions. ${ }^{941}$

Knodel and van de Walle looked at 10\% increment declines in marital fertility between 1800 and 1970. The demographic and socioeconomic indexes that they considered were the marital fertility before the decline, index of proportion married, overall fertility, infant mortality (per 1,000), per cent of male labor force in agriculture, percent rural, percent in cities over 20,000 and per cent illiterate. For Norway, the date of decline in marital fertility by $10 \%$ was 1904 . The date of that same $10 \%$ decline phenomenon in Sweden was 1892, Denmark, 1897 and Finland, 1908.942

In their study, Knodel and van de Walle fix Infant Mortality (per 1,000) for Norway in 1904 as 76, the Percent of Male Labor Force in Agriculture was 37\%, percent rural was $72 \%$, the Percent in Cities over 20,000 was $18 \%$ and the percent illiterate was "low." 943 The ranking of countries in terms of the date of this $10 \%$ decline in marital fertility, beginning with France (1800) was, Belgium (1882), Switzerland (1885), Germany (1890), Hungary (ca. 1890), England and Wales (1892), Sweden (1892), Scotland (1894), Netherlands (1897), Denmark (1904), Austria (1908), Finland (1908), Italy (1910), Bulgaria (1912), Spain (1918), Ireland (1929), Costa Rica (1962), Taiwan (1963), Chile (1964) and Thailand (ca. 1970). In other words, this was a trend not only in the Scandinavian countries but also throughout Europe and throughout the world

939 John Knodel and Etienne van de Walle, "Lessons from the Past: Policy Implications of Historical Fertility Studies” in Population and Development Review, 5 (1979), 217-18.

940 While this may seem like a very long period of time, I thought it necessary to balance the picture in the first paragraph from only 1977.

941 Ibid., 219.

942 Ibid., 221, Table 1.

943 Ibid. 
at the turn of the century which the advent of accessible contraception would change further.

Knodel and van de Walle also calculated three indices; they were Ig (level of marital fertility before the $10 \%$ decline, Im, Index of Proportion Married and If, overall fertility. They also examined a time series for the index of family limitation, a value they labeled “m.” In all the countries studied, once the $\mathrm{m}$ value rose above a minimal level and once the Ig index started to fall below the predecline level, the fertility trend toward decline "continues virtually uninterrupted until radically different levels are achieved." "944 This observation confirms "the fertility transition results from a new form of reproductive behavior rather than from an extension of previously established patterns." 945

As was seen in Case One, the lowering of a nation's population can also be the harbinger of debates about the role of women and her role in the family or as a worker as well as about those who were unable to work, as well as immigration or racial/ ethnic participation in civic life. On New Year's Day, 1978, the Aftenposten began the New Year with an article on global population. The SSB had, for the first time ever, joined in an investigation with the World Fertility Survey, ${ }^{946}$ to investigate why the number of children in Norway had decreased. ${ }^{947}$ Three groups were to be investigated; one survey would be answered by everyone in the survey group, one by married cohabitating couples and one by a group that had never been married or had co-habitated. Women would be asked a number of questions about their living situation, how they had been raised, their education, income, professional work history, and pregnancy history. Their pregnancy history would include how many, if any, of their pregnancies had ended in an abortion. If the pregnancy was carried to term, they would be asked the possibilities of help with the child, the amount of time they devote to the child, and if they had a modern or traditional attitude toward their quality of life. ${ }^{948}$

This research was based, in part, on theories held by Professor Richard A. Easterlin, who was based in the United States. An SSB consultant, Helge Brunborg, had studied Easterlin's population predictions, already considered controversial. Easter-

944 Ibid., 233.

945 Ibid.

946 This survey is described as a global survey, meant to investigate why there were consistently fewer births in industrialized nations. Please see "The World Fertility Survey" in European Demographic Information Bulletin, Vol. 4, No. 1 (March, 1973). Also see the on-going work of the survey at the Office of Population Research at Princeton University, http://opr.princeton.edu/archive/wfs/ last accessed 10 August 2009 and at the U.S. National Institute of Health, http://www.ncbi.nih.gov/pubmed/12311520?/og\$=activity, last accessed 10 August 2009.

947 Aftenposten, 2 January 1978, p. 9. Author, Trine Hay. Please see, Richard Easterlin and Eileen A. Crimmins, "Exploratory Study of the 'Synthesis Framework' of Fertility Determination with WFS Core Questionaire Date” in WFS Scientific Reports, No. 40, (London: World Fertility Survey, 1982).

948 Ibid. 
lin hypothesized that people's preferences toward how many children they had and toward their material consumption were based on the conditions in which they themselves had been raised. If their expectations were not fulfilled as adults in relation to what they had as children, they would reduce the number of children they had. Since those born in Norway in the 1930s became adults in the 1950s, at a time of comparatively better economic conditions, it was thought that Easterlin's theory could be tested in Norway. The reporter noted that in the middle of the 1960s birth control had become available in most industrialized countries, including Norway. ${ }^{949}$

Even if controversial, Easterlin did provide an analytic framework for the study of fertility that continues to this day. The use of statistics is paramount in his work and he sometimes uses fertility as an independent variable to "help explain some intractable aspects of social life."950

In Norway in 1978, it was not concern over the "right" type of population as in Case One, where large numbers of immigrants had resettled in the United States and were having large families. The "moral panic" that fueled this crisis contained fewer factors. It was a leaner "moral panic" than we saw in Case One in both countries, devoid of any "progressive" aspirations, without an observable eugenics movement and mainly concerned with the intersection of gender role schemas and religious structures, i.e. DNK and members of the FASA who were members of DNK or another Church with similar dogma regarding sex and sexuality.

If it was possible that abortion might be allowed in Norway, then it made sense to know exactly how many applications for an abortion had been made in the recent past and to analyze them. In March 1978, Psychiatrist Berthold Grünfeld (1932-2007) wrote an article for Aftenposten about this issue and its implications in which he analyzed this data from the Ministry of Health for the last 4-5 years. ${ }^{951}$ The number of live

949 This article in Aftenposten was accompanied by four other articles on one page, situated later in the newspaper; they were entitled "Fewer Norwegians at the Turn of the Century?", "Two Children are Enough - No children not an option", "Eight Children, One Dog, Cat and Turtle" and "Fewer and Fewer Births.” (Aftenposten, January 2, 1978, 17.)

950 Aftenposten (a.m. Edition), March 7, 1978, 2. Grünfeld wrote his dissertation on abortion and was awarded a doctorate in medicine in 1973. In 1993 he was made Professor of Social Medicine at the University of Oslo. He was born in what was then Bratislava in Czechloslovakia and in 1939, along with 34 other Jewish children was taken by train to Norway by The Nansen Help ("Nansenhjelpen") and Women for Peace and Freedom ("Kvinneligaen for fred og frihet”). Please see, http://www.wikipedia. org/w/index.php?title=Berthold_Gr\%C3\%BCnfeld\&printable=yes, accessed Sept. 19, 2007.

951 Nicholas Townsend”,Reproduction in Anthropology and Democracy" in David I. Kertzer and Thomas Fricke (eds.), Anthropological Demography: Toward a New Synthesis, (Chicago: University of Chicago Press, 1997), 98. Since 1978, however, features of this framework have been questioned, for example, that "fertility" is taken as "unproblematic" and that these models are "directed at the left hand, independent variables or causal side of the model[s]." (Ibid.) As Townsend argues, the underlying definition of "fertility" in Easterlin's work is not questioned by such factors as cohort, period, age and parity-specific measurements. The second feature of "fertility" in these frameworks that can 
births per year in Norway had fallen since 1973 after staying "surprisingly stable" at 65,000-69,000 prior to that date. This trend was also mirrored in Sweden. The number of abortions had also begun to stabilize in 1974 with approximately 15,000 each year. Eight of one hundred women between the ages of 14 and 44 became pregnant in 1977; two of those eight ended in abortion and six of eight pregnancies resulted in a live birth. Grünfeld noted that this "confirmed one thing”, i.e. that Norwegian women were "very diligent, responsible and conscientiously using birth control." 952 In 1977, 100,000 women used the birth control pill as their primary form of birth control, with another 150,000 women using intra-uterine coils and another 100,000 using condoms. Grünfeld interpreted this to mean that 2 of 3 Norwegian women had access and used "good and effective birth control."953

If this were in fact true, then why, Aftenposten asked, was there still a need for abortion? Grünfeld answered that in 1976, one of every four abortions that took place involved young women in their teen-age years. Still, $60 \%$ of all teen-age pregnancies ended in births. Technical failure also accounted for a number of unwanted pregnancies. The failure rate for an intra-uterine coil accounted for 2,000 to 5,000 pregnancies in 100,000 women per year. If 150,000 women used that method of birth control, then one could calculate 3,000-7,500 unplanned pregnancies per year, some of whom may want abortions. Human failure was also a factor in unwanted pregnancies. Regarding the population as a whole, Grünfeld's opinion was that, on an average, every Norwegian ${ }^{954}$ had 1.1 children during the course of a lifetime, unlike Sweden where the number of pregnancies was "sinking drastically." 955

Just as in both the American and Norwegian section in Case One, the role of women in society was a matter for debate in 1978. The issue of whether or not women should work outside the home had never really been settled for some members of either society with the exception of contributing to the home front war effort in World War II. That more and more women either chose to or were forced to work outside the home either through economic difficulties or death of a partner was, however,

be questioned "is the feedback from fertility as the dependent variable to fertility as an independent variable"; the feedback loop may have a causal arrow from "cumulated family size" to "reproductive history" or from "fertility" to "institutions, social and economic structure, norms; external conditions, etc.” (Ibid., 99.)

$952 \mathrm{Ibid}$. The population of Norway 1977 was approximately 4,035,200 million. (http://www.populstat.info/Europe/norwayc.htm, accessed November 6, 2009). If 50\% of that population were women, then we have 2,017,600. In general a population has women in the proportion of $1-14$ yrs. Old (19\%), $15-59$ yrs. old $(60 \%)$ and $60+$ yrs. old $(21 \%)$, then the number of Norwegian women between the ages of 15 and 59 in 1977 would have been approximately 1,210,560. (http://www.popuplstate.info/Europe/ norwayg.htm, accessed 6 November 6, 2009.)

953 Ibid.

954 This statistic presumably means 1.1 child for every male and female. Norwegian citizenry were procreating to the point of keeping the population stable.

955 Ibid. 
a reality. ${ }^{956}$ That more and more women were becoming better educated was also a social fact. ${ }^{957}$ That the number of female voters nearly equaled male voters in Norway was a fact. ${ }^{958}$ Nonetheless, a conflict inherent in the issue of women working outside the home again came to the surface in 1978. This nature of the conflict was in the question: If women work outside the home, then who will provide the social care that women had provided for centuries that included care for the young and the old as well as the domestic work?

In mid-January in 1978 in the pages of Aftenposten, Sissel Dahl took up the issue of gender equality that most supposed would soon become a legal reality in Norway along with self decided abortion. She was surprised to find that within the business community fulltime jobs for women had increased only 4\% in 1977; her opinion was that they should occupy between 35 and $40 \%$ of fulltime positions. ${ }^{959}$ She was supported in this opinion by Kari Vangsnes, of the The Equality Commission, ${ }^{960}$ who voiced concern over the tendency for married or previously married women who were hired for "part-time jobs", defined as less than 30 hours per week. Between 1974 and 1976, there had been a noticeable increase in this type of work in the "service" industries - hotel and restaurant workers - as well as in the banking and insurance sector and in the health and social services sector.

The issue of women in the national work force had not gone unnoticed and had been researched. Arbeiderbladet ran a review of Harriet Holter's book, Women's Life and Work in its Culture section on 4 January 1978. ${ }^{961}$ The review, written by Ruth Johnsen, was entitled "Sex Roles and the Development of Society", something that seemed to be a new concept for newspapers of the day. In addition, Johnsen, who was a women's consultant at the District Work Office in Oslo and Akershus, had not just one, but three articles published by Arbeiderbladet. They focused on gender stereotyping, women and work possibilities and the politics of women's employment. ${ }^{962}$ One of her articles dealt specifically with the Resolution of 5 August 1977, which said that all citizens between the ages of 16 and 60 had a right to paid work. ${ }^{963}$

956 Lønna, Stolthet og Kvinnekamp: Norske Kvinnesaksforenings, p. 159. Note 1106. Also see, Arnlaug Leira, "Kvinner i lønnsarbeid og ulønt arbied” in Thordis Støren and Tone Schou Wetlesen (eds.), Kvinnekunnskap (Oslo: Gyldendal Norsk Forlag, 1976), 119-37.

957 Ibid., 287.

958 Thordis Støren and Tone Schou Wetlesen, eds., Kvinnekunnskap (Oslo: Gyldendal Norsk Forlag, 1976), 201.

959 Aftenposten (a.m. Edition), January 14, 1978, 36.

960 Likestillingsrådet, see http://www.kampdager.no/arkiv/forskning/artikkel haavind.html, accessed April 4, 2010.

961 Arbeiderbladet, January 4, 1978, 14.

962 "Kvinnersvalg av yrke og utdanning”, Arbeiderbladet, January 5, 1978, 14 and "Fylkesarbeidskontoret”, Arbeiderbladet, “Kvinnene i sysselsettingspolitikken”, January 6, 1978, 13.

963 Ibid. 
One sector of society that quickly derived benefit from the agitation for gender equality was the military. In early March, Erling Norvik indicated in a speech at Haugesund that women reserve personnel in the military would henceforth be paid on a differentiated scale according to her rank rather than of a fixed sum for participating in courses and exercises. ${ }^{964}$

\subsection{Cascading Intersections: Parliament, the Law, Abortion and the State Church of Norway}

As was seen in the American half of this comparison, religious institutions played an important political role in policy making. ${ }^{965}$ It is perhaps easier to see the role of religion in the abortion issue rather than in the use of birth control methods, since - if the Roman Catholic Church is an example - it took a period of time before its "official" position on synthetic hormone birth control technology coalesced. Norway's state church and other conservative forces had already been involved in working against abortion during the inter-war period. At the end of the 1950s the liberalization of Norway's abortion laws became an issue - again. Finally, in 1960, the Norwegian law was changed to allow for abortions if there were sufficient "social-medical" indications that one was needed. However, a woman needed to apply to a panel of doctors and this situation continued until 1978. DNK and the "free churches" advanced the most strident opposition to this legal situation. ${ }^{966}$

Between 1960 and 1978, the reasons for liberalization of the Norwegian abortion law were very similar to those used in the United States. Whatever abortion laws were in force in the individual states within the United States were no deterrent for women with money. If a working class woman wanted an abortion she was subject to unpre-

964 Arbeiderbladet, March 1, 1978, 8.

965 It is often difficult to extract the role of religion in political affairs. Nonetheless, we do have historical cases that are instructive. What the Weimar Republic and apartheid-South Africa are to legal history and jurisprudence, the actions of the Roman Catholic Church in Nazi Germany are to the interaction of religious and political ideology about reproduction. The Third Reich and the Church clashed over control of reproduction - among other things. As Paul Weindling notes with reference to the January 1, 1934 law, "Law Against Compulsive Criminality”, that when the draft law was presented to the the German cabinet on July 14, 1933, Franz von Papen "objected that the state of [...sexual] diseases was curable and that the Catholic Church could not allow the state to usurp control over reproduction." Paul Weindling, Health, Race and German Politics Between National Unification and Nazism, 1870-1945 (Cambridge: Cambridge University Press, 1989), 254. This issue of who controls reproduction is often a matter of patriarchal and patriarchal-type power, whether comes from political or religious quarters - or a combination of both.

966 "Free churches" refers to what might be called "low-church" chapels. The physical trappings of DNK are not present and they are more "protestant" in appearance and in style. They are also, generally, more fundamentalist than the majority within the DNK itself. 
dictable treatment at the hands of a person who may or may not have had any medical education and who was not regulated by any market forces since s/he could charge what s/he wanted for the illegal procedure. In other words, unequal access to medical care was an issue. One type of treatment could result in a full life, well lived and productive and the other in death. But the fact of abortion clashed with what churches believed was the worth of the human (fetal) being which could be traced to both the Christian and the humanistic tradition. ${ }^{967}$

In 1978, the Parliamentary session that reconsidered the abortion issue also implicitly - reconsidered the relationship between the state and the state Church. The Norwegian Constitution §2 granted freedom of religion, but the DNK remained the official state Church in 1978. Section 2 of the Norwegian Constitution read:

All inhabitants of the Realm shall have the right to free exercise of their religion. The Evangelical Lutheran religion shall remain the official religion of the State. The inhabitants professing it are bound to bring up their children in the same. ${ }^{968}$

But when the new abortion law was passed, some DNK priests felt that they could not continue as priests and agents of the state Church. An indication of the impact of societal shifts on DNK and its relationship to the state was seen in the protest by Børre Knudsen (b. 1937), a vicar in Balsfjord, as well as in the resignation of a Storting representative who was also a priest, Per Lønning.

After the new abortion law came into effect on 1 January 1979, Knudsen refused to carry out certain duties of his official state office. ${ }^{969}$ Knudsen continued as the priest in the local church but, as part of his campaign against the state, Knudsen renounced his oath of office, broke all communication with anyone who had connections with the official state church, and neglected to carry out consecrations - mostly marriages - all the while refusing to take his salary from the state. ${ }^{970}$ Knudsen's reasoning for his refusal to yield to state authority was that the new abortion law was in conflict with the common idea of the worth of human beings and with DNK as the state religion under $\S 2$ of the Constitution. He reasoned that the state had deprived itself of the right to undertake the administration of the church and his goal was to use the abortion law in a legal challenge in order to clarify the state church relationship. ${ }^{971} \mathrm{He}$ proposed a "strike" of bishops and priests wherein they would relinquish their official status - and salary - from the state. However, only one priest, Per Kørner, joined ranks

967 Bernt T. Oftestad, Tarald Rasmussen and Jan Schumacher, Norsk Kirkehistorie (2nd ed.) (Oslo: Universitetsgforlaget, 1993), 284.

968 Flock, Lassen, Bull, Tronslin, eds., Norges Lover, 1687-2003, 1. Note 831.

969 Bernt T. Oftestad, Tarald Rasmussen and Jan Schumacher, Norsk Kirkehistorie, 285.

970 Ibid.

971 Oftestad et al., Norsk Kirkehistorie, 285. Note 1156. 
with Knudsen. ${ }^{972}$ Essentially what Knudsen managed to do was to bring major events in the social life of Balsfjord to a halt. Couples could not be married and neither could their marriages be registered with the state. This inability to register marriages went beyond halting social life however since it also had economic implications.

Knudsen's strategy in pursuit of his goal was in direct opposition to that used by the College of Bishops and Oslo Bishop, Andreas Aarflot (b. 1928). Their position was that the relationship between the church and the state should be changed, but it should be changed through a common political process, rather than through the more militant Knudsen model. What was at issue was the type and measure of force that DNK could bring to bear against the state; Knudsen believed he could force the state to abandon the new abortion law whereas, in a more moderate fashion, Aarflot felt DNK could only "instruct" the government as to the right and wrong of its law-giving function by having it consider the rulings passed by Bishops on various issues. ${ }^{973}$

Eventually, in 1983, Knudsen had his legal case come before the Supreme Court. ${ }^{974}$ The state wanted Knudsen removed from his office on the grounds that he had renounced his oath of office and had failed to provide services for the citizens of Balsfjord by taking the official seal used to register marriages, etc. ${ }^{975}$ The Supreme Court squarely faced the issues presented by Knudsen as to $\$ 2$ of the Norwegian Constitution saying that $\S 2$ of the Constitution could not be understood as to "create barriers for the state's law making ability." 976 The state's only duty was to provide for the administration of the Church. There was no need for a judge of the Supreme Court to rule on the abortion law since the Parliament had lawfully passed it. ${ }^{977}$

Knudsen's reaction should be seen in the structural and schematic contexts of the day. The 1970s were a time when people were ready to explore other forms of belief, even including Eastern religions. The membership of virtually every Western denomination declined, except for perhaps those involved in the evangelical movement. In 1938, the membership of DNK was $96.5 \%$ of the total population. In 1960, that figure had not changed much; by 1991 the figure was 90.5\%. A 6\% drop in membership may not signify as serious a change in religiosity as I allude to here, but membership and

972 Ibid., 285-86.

973 Ibid., 286.

974 Rettstidende 1983 s 1004 . Knudsen's legal challenge also relied upon the Norwegian Constitution §4 (The King's duties toward DNK), the European Convention on Human Rights (20 January 1966) Art. 4 (No slavery, forced or compulsory labor) and the United Nation's Declaration on Human Rights (December 10, 1948), Art. 3 (Right to “life, liberty and security of person”).

975 Bernt T. Oftestad, Tarald Rasmussen and Jan Schumacher, Norsk Kirkehistorie, 286. The official seal must appear on a document for it to be considered legal. When Knudsen took his his seal, which was used as part of his position out of circulation, this interfered with the operation of government. 976 Ibid.

$977 \mathrm{Ibid}$. Knudsen lost his challenge but, through use of a resolution, he was allowed to remain an ordained priest. 
attendance are two different phenomena. Chaves and Cann argue that a state Church is a "source of a low degree of religious pluralism and, therefore, of low participation in organized religion." 978 While DNK was used for memorializing various life passages, attendance after World War sunk and remained low. In 1958, 2.9\% of the population routinely attended Sunday services; in 1978 that figure was $2.5 \%$ and in 1990 , $3 \% .{ }^{979}$ During the 1970s, DNK also lost about 60,000 members and Church membership, as measured by the number of children baptized in the DNK, had decreased. ${ }^{980}$

Another indication of religiosity in Norway is the number of Norwegians who were leaving DNK around 1978. Figures of DNK membership were inflated in any event since all Norwegians who were not registered with another faith, were presumed to be members of DNK. In 1970, a record number of Norwegians $(7,205)$, presumed to be members of DNK, followed an administrative procedure, and opted out of the Church. ${ }^{981}$ The next peak of Norwegians leaving DNK was in $1978(11,230) .{ }^{982}$

These figures show that while structures and schemas supporting the DNK were in place before World War II, by the late 1950s, they had, to a small but significant extent, changed. Membership that required church attendance is not practiced in Norway. However, even though regular attendance was not a rule, Norwegians continued to use DNK and DNK rituals to memorialize significant life passages, i.e. for birth (Baptism), adulthood (Confirmation), commitment (Marriage) and death (Funerals). This was a new practice in light of pre-War II schemas and indicated a significant change in what the structural entity of DNK meant in the lives of Norwegians. Flocks of believing worshipers began to absent themselves from regular attendance in DNK. By 1978, they would appear in DNK when a member of their family was born, came of age, married or died, although the number of families engaging in these rituals was also decreasing. ${ }^{983}$

As important as some felt the equality issue was, it was not equal rights that occupied the political center stage in Norway in 1978. The abortion debate was the main issue in 1978, just as it had been in 1934, in large part through the work of a grass roots religious movement that had formed in response to the passage of the 1975 abor-

978 Robert J. Barro and Rachel M.McCleary, "Religion and Ecocnomic Growth across Countries" in American Sociological Review, 68 (2003): 761 citing to Marck Chaves and David E. Cann, "Regulation, Pluralism, and Religious Market Structure" in Rationality and Society, 4 (1992): 272-90.

979 Ibid. p. 298.

980 Ibid.

981 Knut Lundby and Ingun Montgomery, eds., Statskirke i etterkrigs samfun: Kirkehistorie og sosiologiske synspunkter på Den norske kirke etter 1945 (Oslo Bergen Tromsø: Universitetsforlaget, 1981), 71. Whether or not the factor here, that fewer Norwegians attend DNK church services, means that fewer Norwegians are religious is another question. What it does mean is that fewer Norwegians were routinely exposed to official DNK doctrine.

982 Ibid., 73.

983 Ibid., 80. 
tion law, a law aimed not only at abortion. This group, FASA, was very active in the debate over whether or not a woman had the right - for herself - to choose to have an abortion. Beginning in the spring of 1974, this group had already collected 610,000 signatures against the new abortion law that they believed would come before the Parliament in the fall of $1974 .{ }^{984}$ Hans Olav Tungesvik, a KrF Representative in Parliament from 1977 to 1985 from Hordaland, had been the Chairman of FASA from 1974 to 1975. By January, 1978, it was his opinion that Norway had assumed the contours of a totalitarian state. ${ }^{985}$

The abortion law had been given a great deal of support from Norway's Labour Party. However, the Labour Party, as the traditional party of workers, also supported what might be called a "conscientious exemption" for health workers who did not want to participate in the actual performance of an abortion. While normally to the left of center, the Labour Party had to consider those members of its constituency who were workers in medical facilities. ${ }^{986}$ It should be remembered that the Labour Party was not the only party that supported "self-decided" abortion in Norway. By contrast, it was the Norwegian Christian People's Party, the KrF, which provided the "most energetic opposition to the liberalization of the abortion law." 987

Tungesvik and his KrF supporters maintained a high level of activity as the 1978 Parliament sat to consider these issues. In January, Tungesvik found out that Health Director Torbjørn Mork had sent a letter to the Chief Administrative Doctor ${ }^{988}$ in Sogn and Fjordane in which he had asked that the abortion committee there "see that the law is practiced in accordance with its intentions." 989 Tungesvik's rhetoric was laced with sarcasm when he wondered if Mork was not satisfied with the number of abortions already being done. ${ }^{990}$ This question of the intent of the law versus its practical applications also engaged the Minister of Social Affairs, Ruth Ryste, She said that it was not Mork's intent to overrule the committee's decisions there, since he, as national Minister of Health, oversaw all abortion decisions made by local committees. ${ }^{991}$ She reiterated the government's precautions against too many abortions, highlighting the 12-week limit within which to have a legal abortion. She also underscored that the government's strong commitment to birth control as a way of reducing the number of abortions.

984 Oftestad, et. al., Norsk Kirkehistorie, 284. Note 1156.

985 Aftenposten (p.m. Edition), January 16, 1978, 4.

986 Aftenposten (p.m. Edition), February 7, 1978, 3 and Arbeiderbladet, January 18, 1978, 5.

987 Oftestad, et al., Norsk Kirkhistorie, 285. Note 1156. “...den skarpeste motstander av liberalisering.” 988 I have translated "Fylkeslage” as Chief Administrative Doctor" since a "fylke” is a "county" or a “district” in Norway.

989 Arbeiderbladet, January 18, 1978, 5.

990 Ibid.

991 Ibid. 
DNK was not the only religious institution to become involved in the abortion debate in 1978 in Norway. For example, Arbeiderbladet ran a letter to the editor from Magnus Tausja, director of the group, Norsk pro vita (Norwegians for life, NPV) on 12 January. ${ }^{992}$ Although the group used Latin in its name, Tone B. Jamholt described this group as a "Christian" rather than a "Catholic" health personnel organization, clearly against any form of abortion and also with strong criticisms of birth control. ${ }^{993}$ Not surprisingly, Tausja supported the right of reservation based on individual conscience. Referring to Mork's press conference of 2 January, in which the Minister of Health asked for all health workers, no matter what their personal opinions, to "show responsibility", Tausja maintained that he had personal knowledge that no catastrophes had occurred for the "few" women who had sought abortions at "so-called peripheral hospitals", and thus, that there was no need for concern. ${ }^{994}$ NPV had fought "beak and claw" against abortion and in February was reported to be starting up an "information office for pregnant women." 995

The "conscientious exemption", also called the "right of reservation" for health workers, was a heated subject in Norwegian newspapers, as we have seen above. Not only had religious personnel and politicians become involved in the abortion issue but doctors also added the weight of their profession to personal opinions. Mork was constantly in the spotlight and it was his opinion, or lack of consistent opinion, to which many doctors directed their most biting comments. On 3 January, Director Mork had indicated in the press that there would be "many difficulties if the new abortion law includes a right for health personnel to refuse to take part in an abortion." "D96 Dr. Per Arne Norum of Oslo responded to Mork's comments by saying "the [real] problem is to be found in Mork's stand on the issue...." ${ }^{997}$ Norum's problem was with Mork's remarks in an article published earlier on 11 May 1974 in which he said first, that the right to an abortion had to take precedence over the conscience of a doctor and second, that any person applying for a medical job had the duty to inform any potential employer of his or her ethical objections to assisting in an abortion. ${ }^{998}$ Norum's questioning of Mork's proposal ended with the intentional use of a German word, when he asked, "In a true democracy, can such a solution ever be taken in the face of those who think differently such that we risk coming nearer to "berufsverbot" (black listing)." ${ }^{999}$ Here is an example of the "cultural stock" that can be used in a social

992 “Norsk Pro Vita”,Arbeiderbladet, January 12, 1978, 5.

993 Arbeiderbladet, February 4, 1978, 7.

994 Ibid.

995 Ibid.

996 Aftenposten (p.m. Edition), January 20, 1978, 14.

997 Ibid.

998 Ibid. “...for opplysningsplikt om etiske holdninger ved søknader - for at man skal unngå problemer med avviklingen av fri abort.”

999 Ibid. 
movement; through an indirect reference to the occupation of Norway in World War II, Norum invoked a broad - and deep - schematic understanding of that oppression. ${ }^{1000}$

But Norum wasn't the only one who could plumb the depths of politically emotional rhetoric with the use of the German language. The same day as his article, Aftenposten published a letter to the editor from Brita Siljan Vogt who asked if women were some type of threat to men who were living a truly Christian life. She was annoyed with the Geilo meeting and wrote that many theologians had interpreted Paul's various and sundry admonitions to women differently from those who attended the Geilo meeting. She closed her letter by asking:

Could we women get concrete information on which fatal and negative consequences would be caused by having women priests?... What if we rebelled against Kinder, Küche und Kirche."1001

While abortion was perhaps the most difficult of issues, it was one of many ancillary issues that dealt with women's equality. Women clergy, the rights of women workers, and fears of what reproductive empowerment meant for the decreasing Norwegian population at large were some of the many other questions attached to abortion and gender equality. For example, how were babies to be categorized if they could not be immediately assigned a notation "born inside marriage" or "born outside marriage." ${ }^{1002}$ What would be their standing in society should this piece of information not be officially noted? Kirsten Mathesen of Kristiansund voiced her deep frustration in late January in Aftenposten when she made reference to the Norwegian White Paper, NOU 1977:35. Here, it was suggested that the only information on a child's birth certificate should be that it was born outside of marriage "until the opposite was proven." ${ }^{1003}$ She called for a protest of this idea, which she said, was a "development that would only make marriage hollow and diminish respect for it as an institution." It was her opinion that to do so would destroy the "natural and correct framework of home and family."1004

The rhetoric of movement framing and re-framing attached to the abortion and gender equality laws had reached the point where German words were being employed, with everything that that implied for this country that had been occupied during World War II. A non-Norwegian observer might well have asked "What next?"

1000 Mayer N. Zald, "Culture, ideology, and strategic framing” in Doug McAdam, John D. McCarthy, Mayer N. Zald, eds., Comparative perspectives on social movements: Political opportunities, mobilizing structures, and cultural framings (Cambridge: Cambridge University Press, 1996), 273.

1001 Aftenposten (p.m. Edition), 20 January 1978, p. 14.

1002 Aftenposten (a.m. Edition), January 24, 1978, 26.

1003 Ibid.

1004 Ibid. 
Since it was the state Church that felt attacked, perhaps it was the penultimate religious enemy that was at work?

\subsection{The Return of Witches: Social Stress and Competing Discour- ses about Abortion}

Anthropologists have shown that societies under stress often resort to supernatural occurrences to help solve issues, laying them to rest. ${ }^{1005}$ Norwegians no doubt thought themselves to be a modern country in 1978, but this did not prevent the devil from making an appearance during this period, in the Vestlandet region. Just as had happened in 1934 when the Church had fought against a less restrictive abortion law and birth control, this exorcism pitted DNK against current scientific knowledge held by medical institutions in Norway, specifically the discipline of Psychiatry.

William Sewell has written about religion and social stress and asks if, when schemas and structures are undergoing stress, is there any way of determining the depth to which societies are under stress or how the stress will be manifested? Sewell notes that structures are at risk "to some extent" every time they shape a "social encounter."1006 This is so, he says, because "structures are multiple and intersecting, because schemas are transposable, and because resources are polysemic and accumulate unpredictably."1007 Structural schemas that are "deep" are "pervasive... in a wide range of institutional sphere, practices and discourses... [and] tend to be relatively unconscious...” In general, religion has such a deep structural schema that it can "mutually tune a people's conceptions of the real with their conceptions of the appropriate way to live." ${ }^{1008}$ Citing to Clifford Geertz, Sewell writes that religion is also about "unsettling human emotions...[and]...the threat of chaos." ${ }^{1009}$ In answer to the question posed in the beginning of this paragraph, the "depth" of the stress that structural schemas are undergoing might be determined by the appearance of religion's main chaotic force and its main adversary, the devil. It should also not be surprising that religion and science should - again - come into conflict in 1978, just as in Case One in the discipline of psychiatry.

In the spring of 1977, a young female student in the town of Os was thought to be possessed by the devil. She had undergone therapy of some type, but, in the end, had also undergone an exorcism under the auspices of the Home Mission for Evan-

1005 Please see for example, Maya Green, "Witchcraft Suppression Practices and Movements: Public Politics and the Logic of Purification” in Comparative Studies in Society and History, 39 (1997): 319-345. 1006 William H. Sewell, Jr., The Logics of History, 143. Note 410.

1007 Ibid.

1008 Ibid., 181.

1009 Ibid., 188. 
gelism (HME).$^{1010}$ In late January 1978, Arbeiderbladet published an editorial cartoon showing what appeared to be a priest holding a woman upside down in his hands. Where the head of the priest should have been, however, were flames and, coming from behind the priest's body, was a serpent-like tail. In the far distance was a crucifix with the body of Christ turned away from the priestly-devil figure. ${ }^{1011}$ The editorial was titled "Cruel treatment of human beings." This was in reference to an interview in another newspaper, Dagbladet, of the young woman who had undergone the exorcism. The information contained in that interview successfully convinced Arbeiderbladet editors that there was very little need for exorcisms but that there was a great deal of influence by the devil on the men in DNK. Arbeiderbladet plainly stated that these adventures by the state church amounted to spiritual charlatanism. It was difficult for the editor to believe that a majority of Church members would defend such a primitive and anti-human behavior. The editor wrote:

If one wanted to protect the victims of these exorcisms from the public, then exorcisms are the most questionable form of protection one can think of. The truth is that it is really the activities of certain agitators in the darkest backrooms that cannot tolerate the light of day." ${ }^{1012}$

In February, a public apology for the exorcism was said to be ready and would be issued from the administrative Board of Directors of the Home Mission since the exorcism had taken place under its auspices. The organization had taken criticism not only in such forums as the Arbeiderbladet but had also been criticized from within; the lead article in the Home Mission's magazine, "For Poor and Rich", had taken a stand against the form of the exorcism. The author of the article, Rector Even Fougner, wrote in Arbeiderbladet that, "Under the circumstances, I would warn against foolish activities when one is dealing with psychiatric problems."1013 But this caution came only after the disclosure that the organization's Youth Ministry Secretary, Oddvar Søvik, had been involved in the incident. Arbeiderbladet reported further that it was "possible" that Sovik's own actions should also be examined by the Board of Directors. ${ }^{1014}$

Arbeiderbladet again took up the issue of exorcism in late April in an interview with Cand. theol. Ebbe G. Reicheit. The "demon-debate" may have been over, for the time being, but in its wake Reicheit had strong opinions about the future of the Norwegian Church in Norway. He wondered if it could be that Christian narrow-mindedness found in a certain type of "piety" that undermines human development was

1010 I have translated "Indremisjonen" as "Home Mission for Evangelism."

1011 "Mishandling av mennesker", Arbeiderbladet, January 31, 1978, 4.

1012 Ibid.

1013 Arbeiderbladet, February 3, 1978, 1, 7.

1014 Ibid., 7. 
itself a form of demonology. ${ }^{1015}$ He noted that a type of piety that finds its expression in wanting what is best for others is quite different from choreographing humans by patterns of commands and forbidden action. For Reicheit, the latter type of piety was a dangerous demon. Reicheit had no time for what Philip Houm had called "church justice."1016 If Christians in Norway were to continue to treat those of different opinions with "cruelty", then this would lead to the fall of the Church, thought Reicheit. As an example, he discussed the abortion debate. It should be the exception rather than the rule, he said, that church folk should try to give their opinions and insights to pregnant women. Rather, it would be better that Christians not take from women themselves the responsibility to make a decision by enacting a law that forbade abortion. Norway should have a law that "acknowledges" this, but church folk must also help the pregnant woman to bear her responsibility.

In the mid-1970s, Norway was again undergoing a period of deep structural and schematic crisis. The exorcism episode supports my argument that state sponsored legislation during chaotic times in the history of a country can be literally inscribed onto and embodied in those invading, and/or foreign, and/or female, and/or nonwhite, and/or lower class and/or disabled bodies. In this case, the Church, the "strong we" impressed its reality on the body of a young female student, a member of the "weak we." The threat of chaos and significant unsettling emotions that the Church hierarchy and membership was experiencing were transferred in the form of the devil into this woman, putting the structure of DNK and the medical structures of the day at odds with each other. Eventually, the medical structures proved more powerful, as we will see below.

In February 1978, a priest named Helge Aarflot wrote an article on the weaknesses inherent in the new abortion law and, in passing, criticized Bishop Georg Hille ${ }^{1017}$ for having said that Aarflot's ideas would split the religious community in half. ${ }^{1018}$ Aarflot was concerned with documents which had come out of the Bishop's meeting in 1977 that made no distinction between protection of both the life in being - of the mother - and the unborn life. Aarflot alleged that some bishops, including Hille, had not continued to support the 1977 declaration and, because of their statements, a split within the church was to be expected. This is not a new idea since what appeared to be a split between rural and urban parishes on the issue of abortion already seemed to be taking place. In general, Bishops from the Oslo, Hamar and other urban areas, had decided against supporting the more radical FASA. But Aarflot felt he had to urge

1015 Arbeiderbladet (Kultur), April 26, 1978, 14.

1016 Ibid. "kirkedommen."

1017 Bishop Georg Hille, Bishop of Hammar from 1974-1993.

1018 Aftenposten (a.m. Edition), February 9, 1978, 3. Helge Aarflot was only described as a "Menighetspresten" which is a priest for a specific DNK congregation. 
the more liberal in the Church hierarchy to "correct themselves" and join FASA as well as align themselves with the Bishop's 1977 statement.

Social Minister Ruth Ryste said in early February that her department "hadn't discussed" changes in the 1 May 1975 abortion law that had already been accepted by the Odelsting and which did include the "right of reservation" for health personnel who had ethical problems with participating in an abortion procedure. ${ }^{1019}$ She said that she and her department were still in the process of working on a draft of the new law. Again, she commented on Torbjørn Mork's year-end remarks as "dangerous" in which Mork had said that to create a "right of reservation" would "create, among other things, different treatment and practical problems at hospitals." A "right of reservation" clause had been an element in the 1975 law and had already created a great deal of conflict. The Norwegian Doctors Association, the Norwegian Nurses Association and FASA had all supported this clause. In addition, Secretary of State Nyhus had commented to Vårt Land ${ }^{1020}$ that no one would be forced to participate in an abortion under the new law.

The issue of a "right of reservation" was the subject of the entire program Short Notice ${ }^{1021}$ on Norwegian television in February. In addition to this NRK-produced television program, an abortion film, produced by a French group, had been imported into Norway by NPV and debate followed as to whom and in what forum the film should be shown, if at all. Questions persisted about its value and even Church and Education Minister Kjølv Egelund said that the film was so "unbalanced and atypical” that it was not suitable as an educational film at all. ${ }^{1022}$

Through the process of framing, social movement organizations hope to achieve both resonance and salience with the general public. But resonance depends on both empirical credibility and the credibility of the framers. And salience depends on a narrative fidelity with the public; in other words, how good is the fit of the frame with the national culture? ${ }^{1023}$ Beginning very early in 1978 both the resonance and the salience of the anti-abortion networks in Norway were under pressure, not only because of the actions of their opponents but also due to the actions of their own members. For example, in February 1978 Bjarne Slyngstad criticized the FASA as an attack against the Labour Party itself. Slyngstad wanted the KrF to stop its "moralizing" since it had been accused by the Labour Party of "combining the abortion issue with politics." Nonetheless, as Slyngstad also noted, there were Christians who were

1019 Aftenposten (p.m. Edition), February 9, 1978, 1.

1020 "Vårt Land" means "Our Country." It is a newspaper produced by conservatives and has a Christian perspective.

1021 I have translated "På Sparket" as "Short Notice." It has the flavor of "off the cuff” political debate.

1022 Aftenposten, (a.m. Edition), February 15, 1978, 3.

1023 Robert D. Benford and David A. Snow, "Framing Processes and Social Movements: An overview and assessment” in Annual Review of Sociology, 26 (2000): 618-622. 
members of the Labour Party and the abortion debate did not follow strict party lines at all times. ${ }^{1024}$ In addition, the fact that NPV had imported the type of movie which Egelund, the Church and Education Minister, would call "unbalanced" only served to undercut Pro Vita's own credibility. In short, in the midst of this extremely emotional political debate, at least one faction started to go beyond what society found acceptable.

But the rhetoric of the abortion debate only reached new levels of fury. In early February, the Oslo Arbeidersamfunns opplysingskontot (Oslo Workers Society Information Office) was threatened. A staff member, midwife Ellinor Fylling, and others in the office who supported the right to abortion received stenciled threats from a man; the threats were mostly of a biblical nature. But the threats were unique in that the workers were threatened with a combination of fire and brimstone as well as the more modern equivalent - atom bombs. ${ }^{1025}$ Part of the reason for the anger may have been that this office had gathered statistics during the 7 years that the group had been in existence. These numbers directly contradicted the logic of FASA and Rø, who claimed that abortion would become a means of birth control. In 1977, for example, this Oslo office had 2622 consultations, 205 of which were for abortion counseling and 2,417 for birth control information.

The group NPV was not to be reasoned with since their first priority was to protect the physical "unborn life" and not the on-going life of the mother or the quality of her family and their lives. To that end, the group had imported the French film, mentioned above, that purportedly had a Christian perspective on the issue. On Friday, 10 February, the male KrF Parliament representatives, a few Labour Party women and others, previewed this movie on the initiative of Labour Party member, Sissel Rønbeck. ${ }^{1026}$ The movie, which was intended for young people, provoked a "sharp reaction" among the viewers. Keeping in mind that the NPV group exceeded even the KrF position on abortion, this could have been expected and, as Tone B. Jamholt reported, the film was purely propagandistic in nature. The film began with an "idyllic" portrayal of pregnancy and birth, accompanied by calm soothing music. Focusing only on the child, the mother was portrayed as smiling while giving birth. The second part of the film was a dark, "grotesque" contrast which showed the abortion of a fetus which doctors considered was over four months old. Blood flows from the woman as viewers see an "arm, a bone and a head" being removed from her. According to Jamholt, the movie was clearly meant to scare young girls. That the movie showed nothing about the particular situation of the mother - or father - went without saying.

1024 Aftenposten (p.m. Edition), February 7, 1978, 3.

1025 Arbeiderbladet, February 4, 1978, 7.

1026 Arbeiderbladet, February 11, 1978, 6. ”Jeg mener filmen kan virake som vold på sjela. Den er ikke saklig, og propaganda har ingen ting i skolen å gjøre. I f.eks. NRK ville man aldri kunne sende en slik film, i alle fall ikke isolert.” 
Sissell Rønbeck made the initiative of showing the film as part of her efforts to question the Department of Church and Education as to whether or not the film was suitable for showing in schools. Her opinion was that the film was propaganda and that, with regard to the national television network, NRK, "it should never release such a film, especially in isolation [without context or rebuttal]." ${ }^{1027}$ Even KrF-member Hans Olav Tungesvik, who viewed the movie along with Rønbeck, felt the first part of the film was fine, but 17-18 year olds should be alerted beforehand as to the content and should make a decision whether or not to see the second half of the film. The rest of the male contingent from the KrF could not understand what Rønbeck meant when she said the portrayal of pregnancy and birth was too "idealistic." For their part, a member of NPV simply said that they wanted to portray pregnancy and birth as "something positive."

In late February, Chairman Magne Roland of the Norwegian Christian Doctors Association and four members of the governing board sent an appeal to the government to withdraw the new abortion law as they believed it broke with medical, legal and ethical principles and 1000 years of legal tradition. ${ }^{1028}$

While DNK, KrF, FASA and NPV strategized as to how to win the war in which they saw themselves involved, tolerance was the theme of an Aftenposten editorial by Haldis Nilson Scarborough on 14 March 1978. Scarborough admitted that tolerance was necessary in a democracy and that it was growing stronger in Norwegian society through pluralism. But, as a Christian, what did this mean for her? Aware of the literature on the subject, she quoted passages from Locke's Letter on Religious Toleration as well as from Martin Luther. The passages she had selected set up a fundamental contradiction between tolerance in a liberal democratic society and Christianity and to understand it differently would be a "misunderstanding of both tolerance and democracy."1029

\subsection{Scientific Discourses and the Challenges to (Religious) Institutions}

The Norwegian Church had clashed with the medical profession at the very beginning of 1978 over the issue of abortion but in March, it became apparent to readers of the Aftenposten that DNK was also on a collision course with modern Psychiatry. Psychiatrist Njål Madland, who had treated the above-mentioned young female student in Os, openly refuted DNK's official version of events that had been given by Bishop Thor

1027 Ibid. Little was Rønbeck to know that eventually the film would be shown on national television.

1028 Arbeiderbladet, March 1, 1978, 8.

1029 Aftenposten (a.m. Edition), March 14, 1978, 6. 
With. Bishop With maintained that he had appreciated how serious the student's condition was and had directed her minister to have a good working relationship with the girl's psychiatrist. That minister understood that the girl needed psychiatric help and made an appointment for her. He continued to discuss this with her in his therapy sessions with her and even made contact with the psychiatrist and asked for advice. But Madlund had a different account of events.

Madland recalled that he had not had contact with either Oddvar Søvik, the National Youth Secretary of the Home Mission for Evangelism or the girl's minister, academic Lecturer and Pastor, Ols Øystese. ${ }^{1030}$ The girl's situation had come to Madland's attention through a request for treatment from the girl's male cousin who had recently moved to Bergen. Øystese had had contact with Madland earlier, after Øystese met with the girl and he became afraid she might commit suicide. At that point Øystese brought her to Madland but at the end of the therapy session, Øystese took her home, which all found to be a reasonable course of action - at that time. But how Bishop With could then maintain that there had been "cooperation" between Øystese and himself was a bit of a "mystery" to Madland. ${ }^{1031}$ That Øystese had made contact with Madland prior to the exorcism was absolutely not true, according to Madland. When he later heard the girl's story, he was “appalled.” He was also "astonished" that they would bring her in for treatment and then take her out of treatment without any warning.

Søvik and his superiors at the Mission Association for Evangelism maintained that both written and oral communication had been made with the girl's relatives and that everything that had happened was with their full understanding. Madland reported, however, that he knew the Bishop had not had any contact with the family until they themselves learned of the exorcism in a letter the girl had written to them after everything had become a matter of public record. As for the male cousin in Bergen, he said he had no idea that there was some sort of demonic presence attached to the events as late as the night before the "séance" in Os. ${ }^{1032}$ As for any "understanding" among the parties, the cousin said he had refused admission to both Søvik and Øystese who had came to his house after the girl had sought refuge with him.

With regard to the assertion that the girl had undergone the exorcism voluntarily, Madland referred back to the fact that Søvik and a "known preacher of the gospel" had sat in one room with the girl, both putting forward the hypothesis that she was possessed. This hypothesis had been confirmed since she would not, or could not, repeat the phrase "Jesus is my Lord." That was in the spring of the previous year (1977) and a first exorcism was performed. The second exorcism then took place in June 1977,

1030 Aftenposten (p.m. Edition), March 3, 1978, 2.

1031 Ibid.

1032 Ibid. 
even though she had felt better after the first. ${ }^{1033}$ She recalled that after these, she had " a good deal of anxiety and nightmares." ${ }^{1034}$ Søvik had written to the young woman the following:

I don't know what you believe or think about me and you probably feel that it is terrible of me to say you are possessed of an evil spirit. But you also know all the signs of this... The question for you now is, will you be free? ${ }^{1035}$

When the young woman later wrote to the General Secretary of the HME, Gunnar Prestegaard, she was referred back to Søvik, essentially meeting a wall of silence from the religious community that had originally sought to help her.

For Madland, the lack of respect that the priests who were involved in the exorcism had for Madland's profession was telling. Also telling was that - according to Madland - they put the "fault" for the exorcism on the girl herself, which was supposedly "voluntary" - after they had sent her a written diagnosis. Madland had himself tried to engage the Bishop in a discussion of the matter but had no luck in doing so. Had the student herself and her family not made contact with Madland, the entire matter would have gone unnoticed and the clergy not questioned about their actions.

This exorcism experience was addressed by the full political spectrum in Norway and HME's behavior was found wanting. That this branch of DNK was receiving such stark criticism signaled a demise in the more moderate DNK population, not liberal but not as conservative as FASA. The more radical factions within DNK, such as FASA and those in an alliance with NPV were also losing credibility with society at large by adopting a "win at any cost" attitude. The religious structures in Norway were shifted and rearticulated into more pluralistic structures with other-than-religious schemas. The questions that remained for DNK at large were varied and difficult and would eventually determine how DNK would enter the twenty-first century.

\subsection{Abortion and the Strength of the Women's Movement in Norway}

March 8th is traditionally celebrated as International Women's Day around the world. It had been almost 70 years since German socialist Clara Zetkin (1857-1933) and other women attending a conference in Copenhagen in 1910 had demonstrated for women's rights. Every year since then, women had decorated the statue of Norway's first feminist, Camilla Wergeland Collett (1813-1895), with flowers in the Castle Park

1033 Ibid. The first exorcism cost 700 NOK; the second exorcism was free.

1034 Ibid.

1035 Ibid. 
in Oslo. While this may have been an annual event, 1978 was especially note-worthy. As Eva Bratholm of Arbeiderbladet announced, the day would be "celebrated as never before!" ${ }^{1036}$ What had become "more and more clear" was that this particular International Women's Day was not simply a day for quiet reflection and modest demands. Demonstrations were planned and Norwegian women were ready to show what concerned them as well as "other central political questions" of the day. ${ }^{1037}$

Pictures of seven women accompanied Arbeiderbladet article of March 8, 1978. Those seven women depicted a range of political parties in Norway at this time. Conservative Party-member Mona Røkke said she would support events in Drammen by talking to people about what the day meant while Turid Varsi would go with her daughter to the Labour Party demonstration in Oslo. Kirsti Grøndahl would give a lecture in Drammen on the national and international aspects of the day. KrF member Eli Kristiansen, however, reported that she would not take part in the demonstration in Oslo and took the opportunity to wonder what women would do if they had two separate demonstrations to choose between, which was in fact the situation. Ambjerg Sælthun for the Center Party said she had so much to do for her work as a Member of Parliament that she would be working at home. While not being against the idea, Labour Party member Mary Eide wasn't sure if she had time to attend the demonstration and Conservative Party member Karla Hafstad said that she would be giving a lecture for women party members in Oslo on the background of the day, i.e. why they should participate and what there was to be gained from doing so.

The demonstration did not begin exactly on the morning of the $8^{\text {th }}$ as planned. Beginning already on the night of March 7th, some women took part in a demonstration against sex discrimination in advertising. Throughout the underground train stations in Oslo, graphically nude advertisements had appeared and women, armed with spray paint, defaced the advertising or tore it down. The women had visited every station in Oslo with the exception of upper Groruddalen. Despite requests from Oslo government officials to the advertising company prior to International Women's Day to avoid problems by not putting the posters up, they had been put up anyway and advertised American pornography in a Norwegian magazine. Odd Øren in the Olso Public Transport's advertising office opined that the appeal from the government hadn't been "right" but also admitted that, in this case, the Norwegian magazine that was involved had "gone over the line."1038

As was noted above, Oslo did indeed have not one, but two women's demonstrations on International Women's Day, 1978. ${ }^{1039}$ Kvinnefronten (The Women's Front), Norsk Kvinneforbund (The Norwegian Women's Association), Oslo Kvinnesaks-

1036 Arbeiderbladet (Reportasje), March 8, 1978, 6.

1037 Ibid.

1038 Ibid. Also see Arbeiderbladet (Reportasje), “Til aksjon med spray boks”, March 8, 1978, 6. 1039 Arbeiderbladet, March 8, 1978, 6. 
forening (The Oslo Women's Legal Rights Association) and Communist groups had organized one demonstration while the Oslo Women's Equal Rights Association had organized another demonstration. The first group was to gather at Youngstorvet and was supported by the groups mentioned above as well as individual members of the Lesbisk bevegelse (Lesbian Movement) and the Nyfeministene (New Feminists). The second group also included representatives from Brød og Roser (Bread and Roses), Nyfeministene and again, the Lesbisk bevegelse. This group marched, beginning from Fridjof Nansens Plass. While both groups had women's equality as a goal, it is safe to say that differences in ideology and strategy had a big part to play in the perceived need for two demonstrations. ${ }^{1040}$ As Elizabeth Lønnå writes, Kvinnefronten and Nyfeministene had "emancipation from capitalism and patriarchy as their main goal" while the Kvinnesaksforening's main objective was equality between the sexes. ${ }^{1041}$ How did Oslo's largest newspaper, Aftenposten, describe International Women's Day activities in Oslo? The afternoon edition ran headlines such as "Women's Demand: Six Hour Workday" and "Women's Slogan: Self-Determined Birth." ${ }^{1042}$ The next day it reported that 3,000 people had taken part in a Bergen and that men had also taken part in the Oslo demonstration. ${ }^{1043}$ While equality might have been the theme for all the demonstrations, the immediate concern of both demonstrations, was captured in a placard which said "Self-Determined Abortion - down with 'the committee'."1044

This demonstration can be seen as the high point of the women's movement at this time in Norway. The fact that there were not one but two marches indicated that - already - the movement was coming unraveled, a victim to radical politics and insider debates. What it did do at this time and place, however, was to demonstrate that the women's movement could put thousands on the street and, as such, had a great deal of political power and that this power was focused on the abortion and gender equality laws that soon would be passed in the Parliament. The same type of Women's Movement occurred in the United States, a bit earlier. However, it too fractured, becoming dormant. After the USSC issued its decision in Roe and the ERA had come close to passing, the women's movement seemed to have lost some of its salience within the every-day life of Americans.

1040 In the three groups - "Kvinnefronten", "Norsk Kvinneforbund" and "Oslo Kvinnesaksforening" - we see a range of reformist versus confrontational styles, in addition to the range of rightleft within the left wing itself. This accounts for some of the differences among the groups. In addition, the thesis of the "United Front" split the two groups. Kvinnefronten was a Maoist's (AKP-ml) "broad front" group.

1041 Elizabeth Lønnå, Stolhet og Kvinnekamp: Norsk Kvinnesaksforenings historie fra 1913 (Oslo: Glydendal Norsk Forlag, 1996), 288.

1042 Aftenposten (p.m. Edition), March 9, 1978, 26.

1043 About 20,000 took part in Oslo. Please see http://www.kamgdager.no/index.html, accessed November 5, 2009 for details relating to the founding of the different groups.

1044 Aftenposten (a.m. Edition), March 9, 1978, 56. 
In and of itself the "right of reservation" for medical personnel might have been a minor issue in the abortion legislation debate except that Norway had a very strong labor movement as part of its history. The political equation that emerged from this had been that workers, be they medical doctors or others, were workers and workers deserved rights. How would the Labour Party, a home to many in the women's movement, address this problem if doctors insisted on a "right of reservation" not to assist during abortion procedures? Doctors continued to employ Aftenposten as a means for discussion of their rights under the impending legislative scheme. ${ }^{1045}$

The struggle over a "conscientious exemption" was debated with intensity not only among health personnel but also within the Ap itself in the Women's Secretariat. Labour Party women made a decision in early April and publicly announced that they were against the right of medical personnel to refuse to participate in an abortion because of personal moral objections. But it soon became obvious that definitions of "worker" within the Ap were changing in light of the broader Women's Movement in Norway. In a letter to the government, the Secretary for the Labour Party Women's Affairs, Aud Blegen Svindland, asked the government not to support such a reservation clause in the soon-to-be-enacted abortion law. ${ }^{1046}$ Svindland, released information to Arbeiderbladet that that group had sent a letter to the government saying that the "right of reservation" by health personnel to refuse to take part in an abortion should not be included in the new abortion law. ${ }^{1047}$ Cabinet minister Kirsten Myklevold told Arbeiderbladet two days later that a clash had indeed taken place within the Labour Party on the right of reservation. ${ }^{1048}$ Myklevold said that there was no consensus whether or not the reservation right would pose problems for women and that "this is discrimination we have now and must work with."

Myklevold was correct about a clash. Arbeiderparti women had found themselves divided on the issue of health personnel refusing to take part in abortions. It was the first time in memory there had been a voting battle in the Ap Women's Secretariet with a final vote of 4-4 on the right of reservation. ${ }^{1049}$ The double vote of the Director - Svindland - was used to create the group's policy against the reservation right. Eventually, the right of reservation was included in the new law and Aud Blegen Svindland announced that she was happy over the new law but not about the right of reservation. ${ }^{1050}$

1045 Aftenposten (p.m. Edition), February 9, 1978, 1. After the election of fall, 2013, the FrP and the Høyre joined forces to again debate the right of reservation.

1046 Aftenposten (p.m. Edition), April 3, 1978, 2.

1047 Arbeiderbladet (Reportasje), April 3, 1978, 11. Apparently, this meant that the women of the Labour Party differed with some men in the party on the issue of a "right of refusal" clause.

1048 Arbeiderbaldet (Reportasje), "Abortloven in Statsråd fredag. Ingen endringer i reservasjonsretten", (continued from page 1), April 5, 1978, 7.

1049 Ibid.

1050 Arbeiderbladet (Raportasje), April 5, 1978, 8. 
In mid-March, a communication by FASA to Social Minister Ruth Ryste brought the abortion issue again to the front page of newspapers. In this announcement, FASA said:

There is a clear relationship between experimenting with artificial life, the demand for self-decided abortion, the death of infants and mercy killings because the worth of humans has become reduced according to its worth as an object of utility. ${ }^{1051}$

The communication itself was signed by Otto Christian Rø and contained six questions. These were:

1. Is the fetus a life different from that of the mother?

2. Is the inducing of an abortion a matter of taking a life?

3. Does the fetus have independent human rights?

4. Does the Director of Health maintain that an abortion performed on demand according to the wishes of the mother is an ethical conflict between the right of the fetus to [the protection of] law and the demand for abortion?

5. Is the duty of society to protect life also implicated with respect to the unborn life?, and

6. How should the fetus' right to life be protected if the woman alone has the decision [to undergo an abortion] ${ }^{1052}$

The reaction from Health Minister Torbjørn Mork to FASA's communication was especially blunt. He called the communication the "most demagogic that I have heard yet."

Hans Olav Tungesvik, a Parliament representative and FASA sympathizer whom we have encountered above, said that he also was a bit surprised to see the linkage between self-decided abortion and test tube babies. Apparently, the FASA material had also made mention of the fear of a Nazi-holocaust situation to which Tungesvik replied:

To have these ideas in the picture now is the work of insane people with sick thoughts and it is not really especially helpful in relation to today's issue. ${ }^{1053}$

Bergliot Børresen, who was described as both a "Christian and an abortion supporter" by Arbeiderbladet, said she saw the FASA comments as "grotesque" especially when making a connection between abortion and in vitro fertilization at the "same time as they were totally silent on the issue of atomic power and the neutron bomb." ${ }^{1054} \mathrm{~B} ø \mathrm{r}$ resen was careful to point out that abortion did show respect for life, the life of the

1051 Arbeiderbladet (Reportasje), March 15, 1978, 9.

1052 “Seks spørsmål til Mork”, Arbeiderbladet, March 18, 1978, 5.

1053 Ibid.

1054 Ibid. 
woman! She wrote that FASA had a historical misunderstanding about abortion as not being permitted during the Third Reich since the point was to produce as many children as possible.

While one of the things that the government did at this time was to respond to frequent attacks by FASA such as the above, another strategy proceeded more quietly without the hysteria provoked by themes of Nazism. Tone B. Jamholt reported in Arbeiderbladet that all cities with 15,000 or more inhabitants would provide education on the use of condoms. To that end, 44 offices were to be set up with additional funding by a supplementary grant of 3.3 million kroner. The State Association for Sexual Information ("RFSU") had, in 1976, sold 10 million condoms through its 3,000 outlets, the most - 30\% - being sold at gas stations. ${ }^{1055}$ The government, the RFSU and the Directory of Health had combined to review a five-year period ending in a 3.3 million kroner grant for this condom campaign. Health stations would also have the duty of providing birth control information and supervision. While in 1976, 94,000 women had relied on the birth control pill with another 90,000 on the coil (IUD) and 4,000 using diaphragms, more outlets were needed to prevent sexually transmitted diseases. The logic in this, the government pointed out, was that pregnant women, whose pregnancies came to term, would have uncomplicated births if they were healthy and not burdened by sexually transmitted diseases.

The new abortion legislation ultimately included a right of reservation for health personnel on the grounds of conscientious objection. Nonetheless, this paled in light of the biggest change in the law as proposed which, when passed into law at paragraph 2, would read:

If the woman finds, after she has received information and counseling, that she cannot go through with the pregnancy, then she herself may make the decision to have an abortion provided that the surgical procedure takes place before the 12th week of the pregnancy and that serious medical reasons do not mitigate against it. ${ }^{1056}$

Essentially, this was a significant change from the earlier law. This law allowed the woman herself to decide what "indications" were present that pointed toward having an abortion. No longer would a woman have to convince a committee why she should be allowed to have an abortion. As Eva Bratholm wrote, the previous system was prone to "over-dramatization" and was essentially a shame-filled practice. From the Department's point of view the practical work that needed to be done was to organize districts so that women would have the opportunity to practice this right regardless of the staffing in any individual hospital. The law also addressed birth control. After

1055 "3 millioner til kondom kampanje”, Arbeiderbladet (Reportasje), April 1, 1978, 8. 1056 Arbeiderbladet (Reportasje), April 5, 1978, 7. 
an abortion, if a woman requested information, she must be given instruction on the prevention of pregnancy. ${ }^{1057}$

Parliament members found a letter signed by 60 gynecologists in their mailboxes later that week. ${ }^{1058}$ The letter, in essence, argued that, should the abortion proposal be passed by the Parliament, a "totally new principle of medical practice" would be instituted, i.e. that the patient herself could decide what course of (medical) action was appropriate. The editorial cartoon used irony regarding this notion; it showed three tall men, coats not unlike white laboratory jackets, bending over a much smaller woman standing naked, clothes strewn on the floor, in the center of their small group. The letter urged the continuation of the committee system. The doctors allowed that abortion would continue in Norway but that the "central" question was not abortion but who decided whether it took place - a woman or the committee members, i.e. medical doctors. ${ }^{1059}$

If the Parliament passed the new abortion law as suggested by the government, what would become of FASA? Otto Christian Rø answered that question by reminiscing that the movement began as a spontaneous reaction against the 1974 abortion law. When Eva Bratholm, perhaps in jest, asked Rø if his group might not join in the antineutron bomb group, Rø simply said that, while it was fine that groups opposed the neutron bomb, his group needed to "concentrate" on the abortion issue. ${ }^{1060}$ Bratholm asked Rø if there were any medical indications that he and his group would accept as reasons for abortion, to which he replied, rather evasively, "This is not something to which we can give a concrete answer." ${ }^{1061}$ By answering as he did, Rø failed to address issues of rape, incest or serious medical complications as a reason for an abortion, again displaying an "all or nothing” approach. Bratholm asked Rø about a previous statement Rø had made, where, in principle, he had said he had no problem with having the issue of whether to allow an abortion submitted to a court of law. Bratholm asked him if this meant that women would be legally forced to carry through with a pregnancy? Rø confessed that he really hadn't meant that; however, there did seem to be a conflict of interest - in his mind - between the fetus and the mother when the mother wanted an abortion. ${ }^{1062}$ The mother was her own attorney but the fetus had no defender. But Bratholm persisted and pressed Rø as to whether or not a woman could be legally forced to have an unwanted child? To this he replied "These are your words, not mine."1063

In its summary of legislative activity in Week 14, Arbeiderbladet noted that the government had finally produced its proposal on abortion. It reported that there was,

\footnotetext{
1057 Ibid.

1058 Arbeiderbladet, April 6, 1978, 4.

1059 Ibid.

1060 Arbeiderbladet (Reportasje), April 7, 1978, 7.

1061 Ibid.

1062 Ibid.

1063 Ibid.
} 
for some, a measure of "joy" in the legislative "breakthrough" but that this had been disturbed by the inclusion of the right of reservation for medical personnel. ${ }^{1064} \mathrm{KrF}$ had also responded to the government's proposed law. As Arbeiderbladet reported $\mathrm{KrF}$ position, the rape of a woman or incest within a family should not "automatically" give a woman the right to an abortion. ${ }^{1065}$ That this followed from that party's point of view wherein life began at conception and should only end "naturally" was no surprise. At his press conference, Olav Tungesvik, the "main person" behind the Party's proposal took time to give his opinion that the birth control device known as the "spiral" also induced abortions. Lars Korvald added that there had been a "tightening" of KrF's position since 1975 on rape and abortion was not to be "automatic" in cases of rape except if it would create serious permanent illness of a psychological or physical nature. Apparently, in the mind of $\mathrm{KrF}$, a woman who underwent rape and who had managed to "cope" with it without serious mental or bodily damage could be forced to carry the pregnancy to term. For some politicians such as these, the issue of abortion was a single issue. For others, the issue had many facets, including the perceived need for abortion. Although the KrF Party excluded consideration of birth control, other parties did not.

In Vestfold, Dr. Georg Bentze ${ }^{1066}$ wrote, it was "meaningless" to continue any discussion on the new law concerning the "right of reservation" for doctors. He analyzed the new law as based on the "Big Brother principle" and blamed Satan for the dictatorship of the Norwegian state over doctors. ${ }^{1067}$

The State Secretary for the Ministry of Social Affairs (1973-1977), Kjell Knudsen (Ap), had kept a lower profile during the March and early April debates but, in April, he began to talk about the issues. At that time, he became too radical for the Norwegian People's Action Against Abortion - or, at the very least, for FASA Chairman Rø. Rø had felt the need to send a letter to Abeiderbladet in mid-April outlining exactly what Knudsen's strategic relationship to that organization was. Prior to that time, FASA had nothing "against" Knudsen. FASA had joined with Knudsen in trying to induce feelings of guilt in politicians for the annual 15,500 abortions in Norway but it was Rø's opinion that Knudsen went too far when he tried to do the same with the People's Action itself. ${ }^{1068}$ In the beginning, FASA had not concerned itself with the issue of birth control. But, in the meantime, it had decided that use of the "spiral" was a means of abortion and not birth control. Rø wrote, in an open letter to Arbeiderbladet, that:

1064 Arbeiderbladet, April 8, 1978, 5.

1065 Arbeiderbladet (Reportasje), April 8, 1978, 8.

1066 Dr. Bentze had moved from Hungary and was an acupuncture enthusiast. His experience with Communism may account for some of his views.

1067 Aftenposten (a.m. Edition), April 19, 1978, 9.

1068 Arbeiderbladet, April 19, 1978, 5. 
He [Kjell Knudsen] asserts that resistance against effective family planning can often be found among People's Action participants. Where did he get this from? (New paragraph) Where have People's Action members tried to instill a feeling of guilt in women who use the spiral? You see, the People's Action has - from its start - not accepted the idea of concerning itself with questions relating to birth control. But the People's Action is fully informed that the spiral cannot be said to be a form of birth control but, instead, as a method of abortion.....Knudsen has several assertions that he hasn't bothered to document. Worse yet, in the meantime, he now tries to influence the undersigned [FASA] that [it] "intentionally concealed evidence of the fact that the number 15,500 represents the number of abortions that take place legally." (New paragraph) Absolutely not! ${ }^{1069}$

Here we can see some harsh criticism within the ranks of those who opposed abortion. Fighting within one's own ranks is usually thought to be reserved for left-wing political circles or, it may also be that right-wing groups are more controlled about washing their dirty laundry in public. In any case, we see some cracks in the unity of the movement. And here, $\mathrm{R} \varnothing$ is not only ideologically angry with Knudsen but is also personally angry at his statements and insinuations. That FASA had a policy of not concerning itself with family planning methods at the inception of the group was clearly changed after the release of certain claims about the use of the spiral.

Aftenposten tentatively entered the fray in late April. In what was a precarious position for a newspaper, Aftenposten took a position on the issue, saying in an editorial that, like some other debates in Norway, this debate was infused with "black and white thinking." ${ }^{1070}$ The editorial first cited KrF-member, Per Høybråten (1932-1990), who had characterized the entire debate as one of "socialist parties" against his own party and its "defense of the unborn life" which was "based on fundamental Christian beliefs." The writer of the editorial found this characterization a "mystery" and wondered how the KrF could criticize the policy since it had never considered the abortion question, first and foremost, as a question of politics. The Aftenposten editorial said:

We consider the abortion question an enormously important and difficult question. We have no difficulty in seeing that this has to do with the right and worth of unborn life. Nor do we have any problem when abortion must be considered a last resort. But we do have difficulties when one, in a manner like this, pretends that it is absolutely a case of an "either-or" matter. In addition, we are - to quote a well-known politician - "disappointed" when the need to stigmatize people with another point of view is given the greater part of the space in a newspaper. ${ }^{1071}$

1069 Ibid.

1070 Aftenposten (a.m. Edition), April 28, 1978, 2.

1071 Aftenposten (a.m. Edition), April 25, 1978, 2. Placed directly next to Aftenposten's lead editorial. "Vi gjenta at abortsaken er en uhyre viktig og vankselig sak. Vi har ingen vanskeligheter med å se at dette har å gjøre med det ufødte livs rettsvern. Vi har heller ikke problemer når det hevdes at abort må være en siste nødutvei. Men vi har altså visse vanskeligheter når man i en sak some denne later som om det skulle dreie seg om et absolutt enter-eller. Dertil blir vi en smule "vonbrotne” for å sitere en kjent politiker - når trangen til å stemple folk med et annet syn gis mesteparten av spalteplassen.” The editorial in that edition of Aftenposten also talks about use of this word. 
The use of the word "disappointed" in this editorial was a clear signal to those that followed politics in Norway. The Norwegian word used was for "disappointed" was "vonbrotne", a word not in normal circulation. But this single word lived on as a commemorative of the comment made by then Parliamentary group leader of KrF, Kjell Olsson Bondevik (1901-1983), when the negotiations he had been asked to lead in order to create a conservative coalition government broke down in 1971 - after just one day of talks - over the issue of admission to the European Union. ${ }^{1072}$ That KrF's insistence on black and white answers for a delicate and serious problem should be its undoing and that the words of its own patriarch such be used against it in a conservative newspaper indicates exactly how tumultuous this issue was. Ideological breaks in conservative politics were beginning to show and show in the public editorials of a conservative newspaper. It could also be argued that the right wing did more damage with this attitude among the general population and may account for some with more conservative views abandoning the middle ground and supporting a more lenient approach to the problem.

Under the new abortion law, only women who were pregnant 12 weeks or less could legally decide on their own to have an abortion. Perhaps as an indication how frantic the political right was, we see a shift in strategy and an appeal to extreme cases that may or may not have taken place at all. Dr. Ola Didrik Saugstad wrote an article about the fact that the division between a fetus and a newborn child was often "blurred." For Saugstad, viewing the fetus as a "clump of cells" involved a scientific myth. As a neonatalogist, Saugstad's opinion was that a better theoretical understanding and better medical techniques were blurring the lines between what were fetuses and what was a new born. This all led to various ethical reassessments. It was also his opinion that allowing abortion was then being reconsidered in a number of countries, including the United States. He credited the American decision in Roe v.

1072 There was also another irony to the use of the word "vonbrotne" ("broken hope") by Aftenposten. When, on 8 March 1971, Kjell Olsson Bondevik, uncle of the later Prime Minister, Kjell Magne Bondevik, had used the word, he was basically acknowledging that his last chance to become Prime Minister had slipped away. He did not live to see his nephew, politician and ordained DNK priest, Kjell Magne Bondevik (b. 1947), become Prime Minister. Bondevik served inthat office from 1997 to 2000 and from 2001 to 2005. I am thankful to Prof. Sætnan for this insight. 
Wade as creating more interest in the debate. ${ }^{1073}$ Finally, Saugstad cited a book by G. Leech entitled "Biokratene"1074 in which Leech says:

By "child liquidation" I mean murder of a child where the parents have taken the alternative after having evaluated that the suffering of the child, a life in being, would be greater than the suffering if put to death. Perhaps one ought to insert two or three days or weeks as a "test life" so that the doctors can check for defects and where the parents take a decision as to whether they wish to keep the child and rear a damaged newborn or not. ${ }^{1075}$

This is interesting rhetoric; it is an attempt by Saugstad to use irony combined with his status as a neonatalist as a means of interjecting himself into the abortion decision-making process.

These two episodes demonstrate that at the macro-political level, the $\mathrm{KrF}$ was losing salience for individuals at the micro-level. Because dogmatic political positions, based in core religious beliefs, were not available for compromise, the framing discourse of the abortion issue had stopped at the micro-level. While an actual decision would later be taken at the Norwegian Parliament to legally allow "self-decided abortion", in one way, the decision had already been taken within society itself. The debate itself had exposed differences, large and small, within the ranks of both the right and the left, but society, as Aftenposten had so succinctly hinted at, was tired of "either-or" thinking.

In early May 1978, the FASA in Oslo increased its attacks on the Ap government. Attorney Gunnar T. Johannessen, who was part of the FASA leadership, took "large

\footnotetext{
1073 Saugstad himself became involved with the American judicial system. His testimony - predictably "anti-choice" - appears in the $8^{\text {th }}$ Circuit Court of Appeals (from Norwegian settled Minnesota, North and South Dakota) in the case of Planned Parenthood v. Rounds (Planned Parenthood of Minnesota, North Dakota, South Dakota; and Carol E. Hall, M.D., Plaintiffs and Appellees, v. Mike Rounds, Governor, and Larry Long, Attorney General of theState of South Dakota,in their official capacities, Defendants and Appellants, No. 05-3093). To date the U.S.S.C. has not accepted certiorari of any case aimed at posing a frontal assault on reversing Roe, although this South Dakota case set up the premier opportunity for the Court to do so. A decision was issued on Rounds in early December, 2007. A 5-4 decision was issued with Judge Souter writing the opininon and joined by Justices Breyer, Kennedy, Stevens and Ginsberg. The basis for the decision was that the "compelled speech" mandated by a doctor to a patient in $\S 7$ of the South Dakota House law 1166 was unconstitutional. However, Justice Scalia took the opportunity to say that the decision ignored precedent and that Roe was wrongly decided. He would have been joined by Alioto and Roberts, but for this statement. Please see, http://sunn. wordpress.com/category/planned-parenthood-v-rounds/, accessed March 4, 2008.

1074 "Biokratene" can be translated as "de somstyer livet" or "those that govern/control our lives." 1075 Aftenposten (a.m. Edition), April 25, 1978, 2. Citation by Saugstad is to G. Leech, Biokratene (Oslo: Aaschehoug, 1971). "Med barnelikvev(r)dering mener jeg drap på et barn der foreldrene har kommet frem til dette alternativet efter å ha vurdert om lidelsen ved å beholde liver vil bli store en lidelse ve å avlive det" Og de innføre to eller tre dager eller uker some "prøveliv" slik at legene kan controllere om det hadde defekter og foreldrene ta stilling til om de ønsket å beholde og oppdrag et skadt spebarn eller ikke.”
} 
caliber shots" at the government's proposed abortion especially paragraph 2, which had also been in contention in the previous 1975 law. This section set out various grounds under which an abortion could be sought after 12 weeks of pregnancy. ${ }^{1076}$ Johannessen's main concern was §2, subsection c. which allowed for an abortion after 12 weeks in cases where there was a "great danger" that the child could be sick due to a serious genetic illness or some illness that the mother had unwittingly contracted, such as rubeola during her pregnancy. ${ }^{1077}$ What Johannessen did not mention was that $\mathrm{KrF}$, in 1968, had indicated they had no problems with this. FASA also arranged for a conference in Oslo where it would present a document detailing reasons against the proposed abortion law to the government. The document was a series of articles by, among others, Per Lønning, author Sigbjørn Hølmebakk and Professor Dagfinn Fellesdal.

At a press conference, Otto Chr. Rø said that the government "no doubt conceived of this new law as an adjustment, from a [Committee consent rate of] of $98 \%$ to $100 \%$ " referring to the consent rate of the Committee who heard abortion petitions. ${ }^{1078}$ But FASA saw the law as a shift in cultural values away from the protection of all life. Johannssen remarked that KrF's position was nearer to what FASA really wanted. But Rø strongly asserted that FASA was not aligned with any particular political party and would try to influence all parties alike. The new secretary for the movement, Anne Enger Lahnstein, spoke from a woman's perspective saying that the impending law accepted male thinking; she thought it true that most women did not want the law but that most men did. ${ }^{1079}$ Lahnstein said the supposed demand for abortion rights "showed contempt for what it means to be a woman and for the desire to become a man." ${ }^{1080}$ She thought that, in newer feminist literature, one got the impression that having a female body was a difficult destiny to bear. For Lahnstein, what was needed was to get away from this idea as well as to ensure that the "womanly function of bearing a child must be a part of gender equality." If this was not done, "then we are in danger of a new type of women's oppression." ${ }^{\text {"1081 }}$ Ruth Ryste responded by claiming "shock" at these newest attacks. ${ }^{1082}$ Although FASA had always used strong language, Ryste said the movement had reached new level of unreasonableness. ${ }^{1083}$

1076 Arbeiderbladet (Reportasje), May 3, 1978, 7.

1077 Hans Flock and Birger Stuevold Lassen (eds.), Norges Lover 1687-2003 (Oslo: Det Juridiske Fakultet at the University of Oslo, Hos Glyldendal Akademisk, 2004), 1008. 13 June No. 50 1975, Law on Abortion.

1078 Arbeiderbladet( Reportasje), May 3, 1978, 7.

1079 Ibid.

1080 Ibid.

1081 Ibid.

1082 Ibid.

1083 Ibid. 
The first weekend in May saw a meeting of the leadership of the women's movement. If the government thought that the right of reservation for health personnel was no longer an issue, they had only to listen to Aud Blegen Svindland, leader of the Labour Party's Women's Secretariet. Her message was practical, yet forceful. In her opinion, no one knew exactly what the right of reservation meant. In which exact arena of the health system did this right come into effect? For her, there were still too many places in the system where women could be brow beaten when seeking an abortion. The solution was, according to Svindland, to abandon the right of reservation for medical personnel altogether. ${ }^{1084}$

By mid-May, Parliament was divided into three factions regarding the abortion issue. The Department of Social Affairs had presented its report supporting "selfdecided" abortion to the Government and, as expected, a majority of the Labour and left-leaning parties supported the report, although the position of two Socialist Left representatives was still unknown. The government's report agreed that women should have the right to decide to have an abortion within the first 12 weeks of pregnancy. Three cooperating political parties - H, KrF and SP - opposed the report with $\mathrm{KrF}$ proposing a more restrictive policy than that accepted by the other two.

The three-party faction mentioned above could not accept that the mother should be entrusted with decision-making regarding the fetus. ${ }^{1085}$ To the Conservatives, the Christian People's Party and the Center Party, it was unthinkable that legal protection for the fetus should be removed during the first 12 weeks of pregnancy, for any reason. The Conservatives and Center Party held a common belief that the law was simply too liberal and "convenient." All three groups underscored the fact that the "indications" or reasons given for an abortion were troubling. The KrF party made it clear that under no conditions would it accept "social" indications as an adequate reason for an abortion. Along with the Center Party and the Conservatives, the KrF party believed that accepting statutory language such as "life-threatening or other circumstances" would only lead down a slippery slope, finally ending in "social" indications. ${ }^{1086}$ It spent its time lobbying for the "right of reservation" by medical personnel. Some thought was given to requiring that women must have every abortion in the vicinity of her home but KrF party members believed this would conflict with the right of reservation.

Edda Espeland warned in the Family Section of Aftenposten on 19 May that the new abortion law could be undermined through the action of some women's groups in their eagerness to have the new law enacted. These groups had sent a letter to all the members of the Social Department that was handling the new law in Parliament. The law, as then written, imposed a responsibility on the doctor to inform the patient

1084 Arbeiderbladet, May 8, 1978, 5.

1085 Aftenposten (a.m. Edition), May 13, 1978, 3.

1086 Ibid. 
about the abortion procedure and its "medical results." ${ }^{1087}$ The women's advocacy groups that had sent the letter had interpreted this to mean that a doctor must tell the patient that a life would be ended by taking part in the procedure. They reasoned that doctors had a general duty to disclose the nature and extent of any medical procedure and how it would be performed. Their opinion was that nothing more should be needed for the medical procedure called an abortion. The groups also reasoned that this would be an opportunity for the doctor to use his authority, or even introduce subjective feelings on the subject in order to influence the women to another, different decision. The women's groups signing the letter were Bread and Roses, The Lesbian Movement, New Feminists, and The Women's Front. ${ }^{1088}$

Espeland made the case for how this type of activity could undermine the new law. The fact remained that the draft law had a clause that allowed the doctor to refuse to carry out the abortion if "weighty medical reasons" advocated against the procedure. ${ }^{1089}$ Kristin Hodnekvam added the observation that if a woman was in such poor medical condition that she could not undergo an abortion, how was it that she could successfully undergo a nine-month pregnancy. ${ }^{1090}$ These women's organizations were also clearly against the imposition of a 12 week cut-off date since, they argued, over $95 \%$ of women who sought an abortion already did so within that period. If a woman must seek an abortion after 12 weeks, forcing her to go through the application procedure, that would only serve to make a bad situation worse. ${ }^{1091}$

The new abortion law had ramifications beyond the obvious. Since abortions were a "necessary evil", state money for birth control and financial help for women with difficult pregnancies was considered a necessary accompaniment to the new law. These two items soon received 2.5 million kroner in aid from the government. Among the initiatives that would be taken, according to Ruth Ryste, was to encourage the use of condoms since, in the one year between 1977 and 1978, 13,000 new cases of gonorrhea had been reported. The KrF party would not support this latter measure. Kjell Bohlen of the Labour Party responded to them by noting that the incidence of gonorrhea in Sweden had fallen 35\% when a campaign of the same type had been used there, but, during the same time period, the number of gonorrhea cases had doubled in Norway. ${ }^{1092}$

1087 Aftenposten (p.m. Edition), May 19, 1978, 6.

1088 Ibid.

1089 Ibid.

1090 Ibid.

1091 Ibid.

1092 Aftenposten (p.m. Edition), May 26, 1978, 4. 


\subsection{The Norwegian Equal Rights Amendment}

In late May, the Parliament also began to grapple with the issue of a gender equality law. On the morning of 24 May, Josef Elias “Jo" Benkow (b. 1924) of the Conservative Party in Akershus began to chair hearings in the Odelsting Chamber of Parliament on a law that would protect the simple, yet legally complicated idea, of human equality. Benkow was reported as specifically addressing concerns of the $\mathrm{KrF}$ party and the Center Party, saying that the goal was to break up the deep-rooted inequality between the sexes that was no longer suitable for a neutral understanding of legislation. ${ }^{1093}$ Two days later, Cabinet Minister for Administrative and Consumer Affairs, Kirsten Myklevoll (1928-1996), testified before the Odelsting Chamber and, in very moderate language, began by noting that both sexes have privileges and weaknesses. The purpose of the legislation would be, according to Myklevoll, to give women the legal right to earn a salary in the workplace and to give men the opportunity to engage in home and local life. ${ }^{1094}$

The gender equality law passed in the Odelsting by a vote of 72 to 40 despite an attempt by the $\mathrm{KrF}$ to add several paragraphs to an existing law, arguing the effect would be the same. Aftenposten noted that after many years of "rambling" and a "good deal of compromise" between the Labour Party and the Conservatives, they had finally made gender equality a legal fact to life in Norway. But questions remained, especially regarding what was called "positive discrimination", known as "affirmative action" in the United States ${ }^{1095}$, or where women might receive preferential treatment in special cases. This still threatened the "big coalition" of right and left. To this, Kåre Willoch - Norway’s "Mr. Conservative" - stepped forward to emphasize that discrimination itself was negative and "something other than equal treatment."1096

All those involved in this legislative debate recognized that practical questions remained to be worked out. One significant question was how would the law be operationalized within unions and professional organizations. Again, Myklevoll put the law in perspective and said that it had never been the goal of the government to create restraints on the handy man or kitchen helper but, by the same token, one had to realize that trade unions and other organizations had a big influence in society and

1093 Aftenposten (p.m. Edition), May 24, 1978, 6.

1094 Aftenposten (a.m. Edition), May 27, 1978, 3. Myklevoll was a LP member.

1095 The most famous case on this issue is Bakke v. Regents of the University of California. Mr Bakke, a white male, complained of the university's refusal to admit him to medical school there, i.e. the university had admitted a woman instead.

1096 Aftenposten (a.m. Edition), May 27, 1978, 3. Willoch began his elected career as a Conservative representative in 1954. He was in Parliament, continuously elected, from 1954 to 1989, a total of thirtyfive years. He was also Prime Minister, serving from 1981-1983 and 1983-1986. His first term was as a Høøre member but his second term was in a coaliton made up of $\mathrm{H}, \mathrm{SP}$ and $\mathrm{KrF}$. 
needed to incorporate the new law. ${ }^{1097}$ Many such organizations had been more eager to protect their privileges than to encourage the process of providing equal rights during the Parliament debate. For his part, KrF party representative and ordained Lutheran minister, Kjell Magne Bondevik, found it "strange" that the courts would have to make a decision about what was an "ordinary theological" understanding. ${ }^{1098}$ Despite this understanding, a Law on the Equality between the Sexes was passed on 9 June 1978. ${ }^{1099}$

\subsection{Abortion as a Challenge to Institutional (Religious) Discourses}

DNK Bishop and Høyre representative, Per Lønning, ${ }^{1100}$ eventually resigned from his Parliamentary post after the abortion legislation was passed. He then authored a document entitled "Therefore...Documentation about the abortion debate and the abdication from office”, in which he outlined the reasons for this dramatic step. ${ }^{1101}$ During the abortion debate, Lønning had been extremely engaged in the running commentary that Aftenposten had presented to the public and was the "foremost spokesman" for DNK in the abortion debate. ${ }^{1102}$ But since the abortion debate had essentially opened a Pandora's box of all things related to human sexuality, and since either Christianity or religions in general, and the Norwegian Church in particular, had views on this subject, Lønning also became caught up in a wave of issues surrounding the more general subject of sexuality. After an overwhelming majority had passed the new abortion law in Parliament, Lønning resigned from the Parliament in protest.

Before Lønning resigned, however, there were more immediate reactions by DNK to the new law since the debate among Church leaders in Norway, their followers and those who had supported the change in the law was not finished. The Lutheran Church in Norway had traditionally used what is referred to as a "pastoral letter" as a strategic maneuver to address what it believed was pressing social and political issues in Norway. ${ }^{1103}$ A twentieth century example of this was the Bishops' letter

1097 Ibid.

1098 Ibid.

1099 Hans Flock and Birger Stuevold Lassen (eds.), Norges Lover 1687-2003 (Oslo: Det Juridiske Fakultet at the University of Oslo, Hos Glyldendal Akademisk, 2004), 1085.

1100 Per Lønning was made Bishop of the Diocese of Borg in 1969. Later, he resumed pastoral duties as Bishop of Bjørgvin from 1987-1994.

1101 Please see, Per Lønning, Derfor...:Dokumentasjon omkring abortdebatten og en embetsnedleggelse (Oslo: Gyldendal, 1975). Also see, http://openlibrary.org/b/OL5005759M/Derfor-, accessed August 12, 2009.

1102 Oftestad, Rasmussen and Schumacher, Norsk Kirkehistorie, 284.

1103 The Norwegian word for this is "hyrdebrev." 
of 9 February 1941, read in church pulpits to protest human rights conditions after Nazi troops occupied Norway. That letter was spread throughout Norway during the wartime occupation and was considered to have had a "very strong effect."1104 It received nation-wide support from Christian organizations as well as from the Free Christian Churches in Norway. ${ }^{1105}$ On 14 February 1942, Norwegian Bishops also sent a letter to priests and parishes on the education of children after it became painfully clear that the Quisling Administrative Office for Churches was determined to indoctrinate a new generation of adherents. These two occasions had been filled with both power and resistance during the occupation. ${ }^{1106}$ This short review of how the pastoral letter had been used in the past only serves to underscore the concern that the Norwegian Church felt when presented with a new, and more liberal, abortion law. In 1978, DNK - again - decided to use a pastoral letter, to be read after the abortion law of 1978 had been passed. ${ }^{1107}$ However, as events unfolded, it was actually read prior to the passage of the new law, creating even more accusations and counter-accusations.

From a structural and temporal standpoint, the pastoral letter - and reactions to it - were what Sewell calls an "act of signification." ${ }^{1108}$ He writes about the storming of the Bastille as this type of event. At that time in France, the social and "political structures were massively dislocated." ${ }^{1109}$ Storming the Bastille was an event that reformed social and socio-religious structures. ${ }^{1110}$ The authority of DNK was placed in

1104 Ingar Hagan, Den Norske Kirken i Storm (Drammne: A.S. Lunde \& Co's Forlag, 1967), 33. Also see, Chr. A.R. Christensen, Norge Under Okkupasjonen, $2^{\text {nd }}$ ed. (Oslo: Fabritius \& Sønners Forlag, 1965), 64. 1105 Hagen, Storm, 89. The phrase "Free Christian" group is a literal translation of "frie kristne" and refers to "low church" groups in Norway.

1106 DNK did resist the Nazis occupation. One such event is worth recounting. By Easter Sunday 1942, about 11,000 Norwegian clergymen had resigned their positions in potest against the Quisling regime; only about 40 remained in their posts. (Many of the clergymen who had resigned died in German concentration camps.) Norwegians were then forbidden to attend a church service in Trondheim's Nidaros Cathedral in February and "thousands" stood before the Cathedral in the freezing cold and sang "A Mighty Fortress is Our God" after Oslo's Bishop Eivind Berggrav had been "locked out" of the cathedral. Berggrav was hauled before Quisling who shouted "You vile traitor! You deserve to have your head chopped off.” To this Berggrav replied, “Here I am.” Please see, Time Magazine, April 13, 1943 at http://www.time.com/time/printout/0,8816,866504,00.html, accessed March 17, 2008. While the Nazi letter had an effect, other letters did not. For example, DNK also sent out what is commonly referred to as a "the culture letter" in September 1945. Written by a committee named by the Church, it "did not have the influence they had thought and hoped for." Please see, Torleiv Austad, "Kirkenkampen - en intermesso?" in Knut Lunby and Ingun Kongtomery (eds.), Statskirke i etterkrigssamfunn (Oslo Bergen Tromsø: Universitetsforlaget, 1981), 24.

1107 http://www.kampdager.no/arkiv/abort/abortkamp/hyrdebrev aksjon.html, accessed, May 18, 2006.

1108 Sewell, Logics, 245.

1109 Ibid.

1110 The timing of the issuance of Church documents that demonstrate "rearticulated events" is not always straightforward. The Roman Catholic Church has also used "pastoral letters", encyclicals and 
the breach in much the same way as governing forces were in France. The issuance of the pastoral letter in Norway and the reactions that followed signified "new meanings that, taken together, reshaped the political world."1111 I think that how Sewell describes the Bastille can also be applied to this event.

[The e]vents...signify something new and surprising. They introduce new conceptions of what really exists.... of what is good, and of what is possible....The most profound consequence of the taking of the Bastille was then a reconstruction of the very categories of French political culture and political action. ${ }^{1112}$

The taking of the Bastille was not simply or merely a physical event in the world; the persons who took part in it were "symbolically motivated" in that they saw the Bastille as an "intolerable barrier to their political hopes" and that symbolism and rhetoric later raced over the world. A cultural transformation had taken place in Norway just as in France. This cultural and social transformation was "both stimulated and locked into place" by "simultaneous shifts both in resources...and in modes of power....” and not even a pastoral letter from the DNK, trying to maintain control over its congregations, could stop these shifts of power. ${ }^{1113}$

The pastoral letter was read in DNK churches throughout Norway on 4 June 1978, although some priests did refuse to read it. Adresseavisen, a newspaper located in Trondheim, editorialized about the pastoral letter, noting that it had caused turmoil within and outside of the Church itself. ${ }^{1114}$ The document was itself very short and read as follows:

agreements for much the same purpose and as a matter of diplomacy. For example, the Reichskonkordat, signed in 1933 by Eugenio Cardinal Pacelli, on behalf of Pope Pius XI, and Franz von Papen, on behalf of German President Paul von Hindenburg, can be contrasted with Pope Pius XI's later 1937 encyclical Mit brennende Sorge, authored by Pacelli. Very simply, these two documents were seemingly at odds with one anther; the first was an attempt to secure freedom of religion for Catholics in Germany and the other was a denunciation of Reich activities. Pacelli became Pope Pius XII in 1939 and is the main character in Rolf Hochhuth's controversial 1963 play, The Deputy. Pacelli is portrayed as a hypocritical pontiff, silent about the on-going Holocaust, the fact of which was well known to him. His silence as Pope stands in opposition to his authorship of Mit brennende Sorge. But, having said this with reference to the use of the pastoral letter by the Roman Catholic Church, it is difficult to reach any other understanding of Norwegian Church's issuance of its pastoral letter than that abortion was not a matter for compromise. Since its inception, the Norwegian nation had been conceived of as a liberal Democracy - albeit, with a state Church - and was built on many ideas including the ability to compromise.

1111 Sewell, Logics, 245.

1112 Ibid.

1113 Ibid., 246.

1114 Hvem, Hva, Hvor 1979: Aftenpostens Aktuelle Oppslagsbok (Oslo: Chr. Schibsteds Forlag, 1979), 73. Here, Aftenposten commented "The new law on abortion has been passed that gives a woman herself the right to decide on the matter within the first twelve weeks of pregnancy. The law has raised 
1. A law has now been passed on access to self-decided abortion in our country. There has, for many years, been conflict on this question, conflict in which the Church has also had a strong engagement, from time to time, but without making statements on this practice for which this law now makes allowances.

2. It is important for the Church to speak out about the situation, which has now developed, while not changing the position for which the Church has fought. The holy Gospel says that humans are created in God's image. This also pertains to unborn life from its inception. The Christian conscience is bound by God's word. A nation's law cannot interfere with this relationship.

3. The Church wants now, in its teachings and in its preaching, to uphold the Bible's view of humanity and the responsibility that implies for embryonic life. This life's need for sanctity and its right to worth must be upheld now more firmly than ever. Through its priests, the Church will seek to lead those who, in dealing with this new law and with those who might experience crises of conscience be they individuals, families, health personnel, and others are disturbed by it.

4. The Church will make every effort so that every single mother, without worry, can bear her child. We would hereby encourage everyone who shares the Church's views to participate in this attitude and action with true Christian compassion. And we will never cease to point out the elementary duty of society to care for adequate social security for all mothers.

5. Protecting the unborn life is not only a matter for the Church. It also concerns respect for human life and human dignity in the entire population of the country. ${ }^{1115}$

The letter was simply dated "June 1978" and was signed by ten persons - (Column One) Tord Godal, Dagfinn Hauge, Bjarne O. Weider, Kristen Kyrre Bremer, Erling Utnem, (Column Two) George Hille, Andreas Aarflot, Sigurd Lunder, Thor With and Gunnar Lislerud. ${ }^{1116}$

Just as its 1941 predecessor, the text was confiscated beforehand, not by SIPO (the secret police) but by feminists. Over 10,000 signatures were collected as a protest against the document in the week preceding the reading of the letter. When it came time for Bishop Aarflot to read the pastoral letter in the Ullern Church, situated near the University of Oslo campus, feminists were organized for an ensuing protest. What they either did not realize, chose to ignore, or may even have capitalized upon, was that that particular Sunday was the 75th Anniversary of the dedication of the Ullern Church and that both the King, H.M. Olav V (1937-1991), and the Mayor of Oslo would be in attendance along with a number of political figures. Because of the presence of the King and other dignitaries, there were a number of television cameras also present.

no little conflict, not the least of which has been in Church circles themselves. In June, ten Bishops of this country issued a pastoral letter, which was read in most of the pulpits in Norway. The contents of this letter caused resentment amongst many by those who saw it as reactionary and not friendly toward women. All of the Bishops and the majority of Christians in this country saw it, however, as important to make known concern for the lack of protection shown the unborn life which they saw as the meaning for the new law. We give here the pastoral letter in full."

1115 Ibid.

1116 Ibid. 
The women and their supporters went ahead with the demonstration. A number of gay men went along to support the women and when Aarflot began to read the letter, the group moved up in the Church, chanting slogans such as "No to the Church's Misogyny" and "Look at the Church's Double Standard" and "Where is the pastoral letter against the [Vietnam] War?"1117 The women unrolled a banner and started to play flutes. Some in the congregation put a "stranglehold" on many of the women and shoved them up against the stonewalls of the Church. ${ }^{1118}$ In retrospect, Marte Ryste remembered that the gay men acted as a diversion for the women and the men received the brunt of physical damage from the Church attendees. ${ }^{1119}$ Eventually, the police, who were waiting outside the Church, arrested the participants in the demonstration and took them into custody. They were each fined between 800 and 1,000 kroner for disturbing the peace, which they refused to pay. They pleaded "not guilty" and explained they had not disturbed a worship service but had demonstrated against Aarflot and his pastoral letter. The matter was set for a trial which, when it happened, was subverted through use of it as a type of "theater." Using total role reversal, men sat wearing dresses and women such as Aud Blegen Svindland, Chair of the Labour Party's Women's Section, wore suits. Svindland also testified as to how the Church had never really cared about women or their human rights. ${ }^{1120}$ The group was eventually convicted and a concert to support the group and to pay their fines was put on at Club 7 by a number of artists who donated their time to the effort. ${ }^{1121}$

As part of the abortion debate that continued throughout the spring of 1978 in the pages of Norwegian newspapers, a parade of various experts with varying opinions throughout the pages of the newspapers took on the appearance of a "war" of experts. In late April, Arbeiderbladet reported that the number of abortion applications had decreased by almost $10 \%$ as had also happened in the same first quarter of the year in 1977. It was the first such decrease since 1964 when an abortion law had been first legislated. But consents for abortion during the same period had risen from 96 to 98.5\%. ${ }^{1122}$ Some 3,909 applications for an abortion had been handled during the first quarter, 408 fewer than the preceding period. So, despite fewer rejections of applications, the total number of abortions had decreased in Norway. ${ }^{1123}$

1117 Please see source, "Aksjonen mot Hyrdebrev" http://www.kampdager.no/arkiv/abort/abortkamp/hyrdebrev_aksjon.html, accessed May 18, 2006.

1118 Ibid.

1119 Ibid.

1120 Ibid. Aud Blegen Svindland would later be recalled as the "mother" of the new abortion law and is a medical doctor. http://www.nrk.no/programmer/radio/solvsuper/5250803.html, accessed May 19, 2006.

1121 Ibid.

1122 “Abort-tallet sinker. Trass i færre avslag”, Arbeiderbladet, April 26, 1978, 7.

1123 Ibid. 
In early May, more stories appeared about the Norwegian Central Statistics Bureau (SSB) and its calculation of the number of abortions. Although the SSB had used numbers from only the first quarter of 1978 regarding abortion figures, Dr. Ragnhild Halvorsen was quoted as saying that she "would not be surprised" if the number of abortion applications would continue to decrease in Oslo. The SSB had indicated that the number of abortions in the first quarter of 1978 in relation to the same period in 1977 and had decreased for the entire country. In fact, the number had decreased 10 percent. ${ }^{1124}$ In 116 districts the number of abortions had decreased and in some cases, by as much as 20 percent. A total of 3,909 abortion applications had been handled in the first quarter of 1978 and were 498 fewer than during the same period in 1977. Throughout the entire year of 1977, a total of 15,941 applications were handled through the Primary Committee; of these, 15,303 or 96\% had been approved and 638 denied. Of those denied, 344 appealed the decision and another 255 were approved, making a combined acceptance rate of $97.4 \%$. Young women below the age of 20 filed the greatest number of applications, accounting for the $42.1 \%$ or the total number of applications. ${ }^{1125}$

\subsection{Society and Institutional Changes: God, Politics and Abortion}

Norwegian Bishops as well as many politicians could not remain silent after the abortion debate. In retrospect, the pastoral letter was only the opening salvo in a national "debriefing" within some segments of Norwegian society. Bishop Tord Godal (1909-2002), head of the Nidaros Diocese (1960-1979), responded to charges made by Labour Party member Geirmund Ihle on 7 June in Aftenposten. ${ }^{1126}$ Godal addressed Ihle's "suggestion" about the timing and manner that the pastoral letter was presented within the DNK. It had been read from pulpits on 4 June 1978 but the law was passed nine days later, on 13 June 1978. ${ }^{1127}$ Faced with this, Godal apologized for the timing of the letter. Despite his apology, Godal had an excuse. The matter had originally been set to come before the Lagting on Friday, 2 June 1978 but, on Thursday, 1 June, it had been postponed one week. Godel noted that it would have been "very difficult" for the Church to adjust its reading of the letter with this short notice.

Godal began his apology by reviewing the opposition the Church had to abortion throughout its history. A Bishop's meeting in 1934 had given serious consideration to

1124 Aftenposten (a.m. Edition), May 8, 1978, 6.

1125 Ibid.

1126 Aftenposten (a.m. Edition), June 15, 1978, 2. Tord Godal was Bishop at the Nidaros Cathedral in Trondheim for almost twenty years, from 1960-1979 and was succeeded by Kristen Kyrre Bremer, 1979-1990.

1127 Law No. 50 of 13 June 1978, “Om Svangerskapsavbrudd”, as amended by law No. 66 on 16 June $1978, \S 4$. 
the Norwegian government's abortion liberalization and again in 1935, 1938 and 1960. The Bishops had also made a common statement in 1971, entitled "Abortion, human opinion and law."1128 Throughout this time period, according to Godal, the Church's position had remained the same. "Unborn life" had also been of "essential concern" to the Church and this was the reason that all churches stood together on this point. The Church would never stop reminding society that unborn life was of value and had the right to life.

Ihle had suggested that the DNK's statements seemed to conveniently come out when the Labor Party was in power and that what the Church really wanted was to control Norwegian politics. ${ }^{1129}$ To this Godal responded that the church had at all times paid attention to the issue of abortion regardless of party politics or personages. Contrary to Ihle's perception, Godal pointed out that the two most important documents issued by DNK in the twentieth century on the issue of abortion had been issued when non-socialist parties had been in power, in 1934 and 1971.

Godal continued his editorial four days later and again emphasized the point that DNK had maintained a consistent policy toward the politics of abortion. Indeed, he had to continue his editorial because Ihle's memory had apparently been better than Godal's as to which governments - socialist or non-socialist - had been in power when the Church had issued its more serious statements. In an article entitled, "The Same Abortion Position Irrespective of Politics”, Godal - again - had to apologize in the opening paragraphs; the DNK's 1971 declaration had not come out under the Borten (non-socialist) government; instead, it had come out under the Bratteli (Ap) government. Godal maintained that all statements, as regarded the 1930s, had been issued without regard to the type of government in power. The 1971 statement had been required since the number of abortions had consistently increased throughout several years. This development was not tied to periods when the Labour Party had been in power, and because of this, Godal could not see how one could say that the Bishop's initiatives were unilaterally aimed at the Labor Party. ${ }^{1130}$

Yet another episode shows show fierce the debate in Norwegian society over the new law was, in contrast to the decade after Roe in the United States. In order to frame and re-frame how society should accept the new law, reliving old political battles before and during World War II - became standard fare in this debriefing process. Willy Møller added his thoughts to the church's actions in an article entitled "What Anger about the Church's Pastoral Letter?"1131 Calling the fury that DNK's actions had induced in the Labour Party "grotesque”, Møller found this reaction difficult to under-

1128 Ibid. "Abort, mennesksyn, lovgivning."

1129 Ibid.

1130 Ibid.

1131 Aftenposten (p.m. Edition), 23 June 23, 1978, 4. 
stand. ${ }^{1132}$ It was true enough, he said, that the Labour Party had been "in general irritating and irritable lately" but the "magnificent salad" of problems that the Government had found itself in regarding a number of issues could not be laid at the feet of any one party. Møller thought the fury must have some other basis, perhaps in the person of Guttorm Hansen (b. 1920), the Labour Party President of the Parliament. ${ }^{1133}$ Hansen had also said that the pastoral letter was a "special form" of Church communication from the bishops and drew a parallel with the letter that had been issued during the occupation in 1941. Møller wrote that Hansen was "obviously ...afraid" that the 1978 letter would have as deep an impact on opinions as the 1941 letter had previously had. Møller believed it could be said that the Labour Party alone could be assessed "full responsibility" for the new abortion law. ${ }^{1134}$ And furthermore, according to Møller, it should be remembered that it was the same party that had the "main responsibility" for what the country had lived through beginning on 9 April 1940 when the Nazis began their invasion of the country. It was easy enough to understand how they would react now, in 1978, with such intensity to anything that "smacked of a pastoral letter." 1135 In other words, the Labour Party should be as embarrassed about the new abortion law as it should be embarrassed about how easily the Nazi invasion had proceeded!

The Labour Party retaliated to this type of debriefing by Møller and others. In a June editorial entitled "When Bishops Carry On Politics", Geirmund Ihle and asked why the Bishops had not issued a pastoral letter between 1963 and 1973 when the number of abortions in Norway had quadrupled. Ihle had argued that this had been a period of non-socialist leadership and so should not be blamed for that increase. ${ }^{1136}$ But Møller then rejected Ihle's conclusion in that earlier article as nothing but "elementary childish thinking" on the part of Ihle. ${ }^{1137}$ Møller said that the Labour Party had "blessed" Nowegians with a law on abortion on 11 November 1960 and all of the abortions that had taken place from then until 1 January 1976, when the Labour Party's abortion law of 13 June 1975 went into full force and effect, were by implication, its fault. Møller noted that the Bishops could have done little during that time. ${ }^{1138}$

Møller also returned to another of Ihle's statements from the same June article, in which Ihle had said that the Church's silence between 1965 and 1973 needed to be contrasted with the 1978 pastoral letter. The Church, according to Ihle, should simply not have involved itself in such an emotional issue. Møller sarcastically recom-

1132 Ibid.

1133 Guttorm Hansen was President of the Parliament from 1973-1981.

1134 Aftenposten (p.m. Edition), June 23, 1978, 4.

1135 Ibid.

1136 Aftenposten, June 7, 1978, 3.

1137 Ibid.

1138 Ibid. "All the abortions from then on until 1 January 1976, when the party's law of 13 June 1975 took effect, occurred under the then current law, about which the Bishops could do very little." 
mended that, as soon as possible, Ihle consult with his fellow party member, Guttorm Hansen, who had said during the Lagting's debate that it didn't bother him if the Bishops became involved in "politics" since it was their right. ${ }^{1139}$ Obviously cognizant of Labour Party literature on the subject, Møller also recommended that Ihle consult the party's editors who had said the Church could "be at hand and become involved and have the right as a democratic constitutional community to make a target of a law that is under consideration." 1140 Møller finished by saying that the Church had a right to become involved in the matter and that he was "surprised" that the press had reacted against the Church and the social problem of abortion since the Church had a long history of commenting on the problem.

As mentioned above, the Conservative Storting Representative and DNK Bishop, Per Lønning, had resigned after the abortion law had been passed. His interpretation of the episode appeared in the pages of Aftenposten in late June. ${ }^{1141}$ In an article entitled "What the Pastoral Letter Disclosed", Lønning made it clear that he was not going to again revisit the Church's position on abortion but to "expose" what had taken place in Norwegian culture during the debate. ${ }^{1142}$ Lønning wrote that a "church that is awake" would have things to learn from the over-heated debate that had just taken place in Norway. ${ }^{1143} \mathrm{He}$ admitted, and this gave weight to Ihle's argument, that the Church, although it had a "prophetic calling", need not enter every debate. ${ }^{1144}$ Lønning was shaken not only by the intensity of the debate in Parliament, but also perhaps by the strident demonstrations, i.e. women "out of place" accompanied by others routinely kept out of sight and out of mind. How such slogans he had read about and had seen could have come into anyone's mind and had been voiced with such force was a surprise to the Bishop, obviously not familiar with some segments of Norwegian culture and society. ${ }^{1145}$

\subsection{Openings for Changes in Other Body Laws}

The use of religious dogma in political debate in Norway had not fared well in 1978 and DNK was keenly aware of this. It was almost unfathomable that the KrF, itself vehemently opposed to abortion in all cases, had indirectly caused the passage of the law itself. The FASA social movement, organized in the early 1970s, had tried numerous framings and reframings of the issue but had lost salience - this time - with the

1139 Ibid.

1140 Ibid.

1141 Aftenposten (a.m. Edition), June 23, 1978, 6.

1142 Ibid.

1143 Ibid.

1144 Ibid.

1145 Ibid. 
Norwegian public. Instead, previously ignored intersubjective groups such as homosexuals ${ }^{1146}$ and the "handicapped" ${ }^{\text {1147 }}$ used this opportunity to organize for their own human rights and push their issues into the public's consciousness.

Numerous body laws can become visible once the one in the body of law begins to take on the appearance of irrationality. The webs of these laws are connected and this is demonstrated by the fact that, at the height of the abortion debate, Per Lønning found time to write an op-ed piece for Aftenposten entitled "Concerning the Church and Sexual Hostility."1148 The term "sexual hostility" referred to Øyvind Foss's edited book in which Foss raised significant concerns with the Church's then-current position on homosexuality. ${ }^{1149}$ At a time when Lønning was as politically engaged as he was and perhaps considering his own resignation from the Storting, this response shows how important the connections among body laws can be.

There were at least two serious problems for Lønning and DNK with Foss’ book. The first was the background of the various authors in the edited work. The book contained articles by Per H. Andersen, a hospital priest at the Ullevål Hosptial since 1975, Sverre Inge Apenes, a priest from Andøy and Drammen and since 1975, a Chaplain for Fagerborg Congregation in Oslo, Svend Bjerg, a lecturer in Systematic Theology at Århus University, Jens Brøndum, a student priest at Danmark’s Tekniske Højskole and author of several books, Tor Edvin Dahl, a supporter of the Pentecostal Movement, and Karen-Christine Friele, General Secretary of The Norwegian League of $1948 .{ }^{1150}$ Bitten Modal, editor of Sirene (The Sirens) ${ }^{1151}$ (1973-1976), and who was also on the Board of Directors of the Oslo Women's Feminist Association (1977) and author of several books including "The ABC of an Abortion Application" and "The ABC of Birth Control" contributed to the volume. ${ }^{1152}$ In addition, the editor of the book had been a priest in Oslo, Tønsberg and Drammen and was then a student priest at the University in Heidelberg. ${ }^{1153}$

1146 Please see, Øyvind Foss, (ed.) En seksualfiendtlig kirke? (Oslo: Gyldendal, 1978).

1147 In September, Aftenposten included a two-page spread on people with diabilities engaged in sports. (Aftenposten (p.m. Edition), September 23 1978, 18-19.).

1148 Aftenposten (a.m. Edition), May 10, 1978, 6.

1149 Øyvind Foss, (ed.) En seksualfiendtlig kirke? (Oslo: Glydendal, 1978).

1150 The Norwegian Association of 1948 ("DNF-48”) was a previously secret organization, founded by and for homosexuals in 1950. From 1966 to 1971 the group agitated against Criminal Code $§ 213$ that made male homosexual acts illegal; these were decriminalized in 1973.

1151 Sirene was a feminist periodical, often portrayed as "pornographic" since it included frank discussions of sexuality.

1152 Foss, Seksualfiendtlig kirke? Information about the authors in unnumbered Endpages.

1153 Ibid. Foss' other books included "Report from Berlin and the Treason of the State Church" and "The Church and the Class Struggle.” Øyvind Foss was the first gay theologian to "come out” during this time. Karin-Christine Friele and her partner would be the first couple to register in Norway under the Civil Union legislation of 1993. 
The second problem was that Berthold Grünfeld, a well-known sociologist had also contributed to the volume. ${ }^{1154}$ Grünfeld contributed salient observations about the role of DNK in Norway and the changes that had taken place in society as well as those that were still underway in Norway. The problem was that Grünfeld's observations were confirmed by the abortion debate and vote. He had written that members of DNK - i.e. Norwegian society - had developed an "open attitude" toward sexuality together with the occurrence of the "sexual revolution." 1155 Grünfeld wrote:

The Church has, to a certain point, has been affected by the secularization process, by ideas from modern psychology and sociology. The Church can no longer attempt to control people's behavior in the area of sexuality by withholding from them knowledge of methods to prevent unwanted pregnancy, as it has done for the last 50-75 years. The intellectualization of society and its democratization make this impossible. Consequently, the Church's techniques of domination have been weakened, and also in this area where it has tried to expand its guardian empire by infiltrating the secular legislation with its system of norms. ${ }^{1156}$

Grünfeld's interpretation of what was happening within secular society had to be answered and Lønning accepted the challenge.

Lønning was given a great deal of space by Aftenposten to present his views. He continued his first article in a subsequent issue of the newspaper, finally finishing on the 16th of May. His final paragraph read:

In short, I do not have enough of a perspective over all the consequences of this issue to make an unambiguous "yes" or "no" [regarding homosexuality]. But the question shall be re-viewed as a question and seriously so. When the Church draws up a vision of Charity based on Biblical faith in Creation, from the Bible itself and its creation story and when it has spread forth the truth on how human recklessness and egoism corrupt all of God's good gifts, can we then think that we can remain in a "no-man's land" such that a human's pressing need to live out his or her sexuality will be ethically legitimated, obviously with the reservations that lie in the sacredness of relationships with one's fellow human beings. ${ }^{1157}$

Lønning had conflicting thoughts on the issue of homosexuality. DNK had said, in 1977 , that being a homosexual was not a problem in its eyes but same-sex sexual practices were a problem, i.e. sinful. ${ }^{1158}$ Nonetheless, homosexuality was being publicly

1154 Foss, ed. Seksualfiendtlig kirke? Note 1336. Information about the authors in unnumbered Endpages.

1155 Ibid., 66.

1156 Ibid., 66-67.

1157 Afternposten (a.m. Edition), May 16, 1978, 6.

1158 Gro Lindstad, Norway in International Gay Lesbian Human rights Commission Report, 137 which can be found at http://www.iglhrc.org/files/iglhrc/reports/2OUR_Norway.pdf, last accessed 3 March 20008. The Roman Catholic Church still follows this type of analysis. In 1993, three Bishops in DNK were of the opinion that this thinking should be changed and that homosexuals, even those in relationships, should be allowed to become priests. As of 2007, all candidates to the Nidaros Cathedral 
considered, not for the first time, but in an open manner, with real names and faces attached to the issue and with the hope of political power.

Other types of bodies were becoming visible. Life for the "differently abled" was beginning to change but challenges did continue. A handicapped woman, Liv Brandvold, wrote to Aftenposten to complain about the shortage of social services for the handicapped. Giving herself as an example, she explained that she had been moved into a special apartment in January 1976 and should have had access to help for 10 hours per week. ${ }^{1159}$ Instead, the Røa health and social center had been unable to send any help at all and she had to rely on friends for help for the intervening two years.

While new energy had been used to advance rights for the handicapped, the stigma of being labeled "handicapped" had also continued, 44 years after the sterilization laws in Case One had been passed. In Oslo, mothers who were actively engaged in the care of their handicapped children faced the societal ramifications of governmental categorization of their children. The Norwegian government had set aside monies available to those children who attended childcare facilities. Appropriations of over 3.5 million kroner for extra help at these nurseries had been made available but the government had discovered that some parents had refused to register their children as "handicapped" and that more money was needed since the number of these children had been underreported. $\mathrm{KrF}$ was opposed to the idea, saying that, despite the requests for more information from some Oslo childcare centers, the numbers were correct as reported. ${ }^{1160}$

Despite the changes in societal structures and schemas, both DNK and the women's movement would emerge from their political encounters as broken, smaller and potentially less powerful institutions. For the time being, political party structures emerged the victor, better able to assimilate the societal changes that had been undergone. And, in retrospect, the law on abortion and equality between the sexes in Norway seemed to be better situated to handle future challenges than its American abortion counterpart and never completed ERA.

\subsection{Changes in the Four Jasanoff Fields}

Representations of what was "normal" and "abnormal" in Norwegian society were impacted by science in this case within the public domain just as in the previous,

Bishopric in Trondheim were asked this question, and all gave this same opinion accepting homosexual unions. Indeed, homosexuality was being publicly considered, not for the first time, but for the first time in a manner with real names and faces attached to the issue and with the beginnings of political power.

1159 Aftenposten (p.m. Edition), February 8, 1978, 13.

1160 Aftenposten (p.m. Edition), April 8, 1978, 8. 
earlier case study. And science was lending the weight of its expertise to legitimize those representations. Medicine as an institutional force in Norway had been under social stress, including pressure from women to be medical doctors, for some time. In mid-February 1978, Ruth Remberg wrote an editorial about the history of women as medical doctors for Aftenposten; the events of 1978 seemed to beg comparisons with earlier times. Remberg began by contrasting the experience of Germany's first female medical doctor, Dorothea C. Erxleben who became a doctor in 1754 "without any major problems" with that of England's Elizabeth Blackwell who had to emigrate to New York in order to attend medical school. Closer to home, Emma R. Heikel had become a doctor in Finland in 1878 and legislation passed in Denmark on 3 June 1870 had sent "a clear signal" to women that the profession was open to them there. Nonetheless, Denmark was one matter and Norway was another.

Seven years after the Danish decision, Livius Smitt, a nephew of Johan Sverdrup, asked the Storting to "clear up" the matter of women doctors. Seven of the eight medical doctors on the Faculty of Medicine at the University in Oslo opposed the idea of women as doctors. Only Professor Jacob Helberg stood for gender equality. Later, in February 1884, E.H. Berner denounced the idea that women should be permitted to sit for university examinations or be permitted to work as civil servants, which he believed to be a natural consequence of the law of 15 June 1882 that allowed women a higher education. ${ }^{1161}$

As usual, variations that the law could never have foreseen came about. Dr. S. Holth married Marie Spanberg (1865-1942) in 1893. She had studied obstetrics in Germany and the two of them began a practice in Kristiania (Oslo). The Justice Department voted to permit this and the right of a woman to practice medicine was enshrined in K.r. 20/11 of 1897. Between 1893 and 1900, 410 men and 19 women sat for the medical examination in Norway. ${ }^{1162}$ The law of 9 December 1912 gave women the right to work as district civil servants and women soon became district doctors. Between 1893 and 1942, the percentage of female doctors remained at approximately the same level - seven percent.

But the institution of medicine would soon be changed as more and more women began to attend university. More would eventually become medical doctors and be admitted to practice around the country. These women were the visible signs that this institution was changing. Women could be carriers of medical expertise. The change in the number of women doctors and student is demonstrated in the following chart.

1161 Aftenposten (a.m. Edition), February 14, 1978, 6.

1162 Ibid. Ramberg mentions 3 of these 19 "pioneers"; Alexandra Ingier, Alette Schreiner, the first woman to become a member of the Videnskapsakademnet, Elise Dethjoff who worked on TB, and Marie Hjølseth, who was awarded the Skjelderup gold medal for her scientific work. 
Table 6.2: Members of the Norwegian Medical Association, $1996^{1163}$

\begin{tabular}{lllll}
\hline & Physicians & \multicolumn{3}{c}{ Students } \\
\hline Age & Males & Females & Males & Females \\
\hline$<30$ & 307 & 391 & 1,042 & 1,031 \\
$30-49$ & 5,766 & 2,670 & 135 & 96 \\
$50-69$ & 3,249 & 619 & - & - \\
$>=70$ & 980 & 156 & - & - \\
Sum & 10,302 & 3,836 & 1,177 & 1,128 \\
\hline
\end{tabular}

An influx of women into medical school and into the profession of medicine began in the age group of 30-49 year olds as of 1996. This meant that these females would had entered school in the years 1976 through 1995, assuming they entered at least as a 20-year-old adult. By 1996, we can see the number of females and males who were members of the Norwegian Medical Association (NMF) who were less than 30 years old was essentially equal. The number of female physicians of all ages who were members of the NMF was also essentially equal with male members of all ages. The increase in female medical doctors less than 49 years old meant that, at least to some increased degree than before, the perceptions of women would be taken into considerations with regard to pregnancy. In addition, even though the work of the midwife had been replaced by hospital stays and medically supervised birth during the course of the early $20^{\text {th }}$ century in the United States, this had not been the case in Norway, where midwives were still routinely used alone or in combination with medical doctors during pregnancy and birth.

DNK was overwhelmed with issues prompted by new scientific breakthroughs and the beginnings of biotechnology. Adding to this, the abortion debate only exacerbated the situation. Abortion as a individual matter, decided in the private sphere rather than in the public realm of the church was originally beyond the comprehension of DNK institutional hierarchy. True, the "defense of unborn life" seemed to have the rhetorical high ground. But the success of the women's movement had, however, been able to capitalize on the discussion about the role of women in society as never before. This movement was so powerful that it was able, as represented in the person of Aud Svindland, to change the thinking of Labour Party women from her identity as a "worker" to that of being of "woman." This was at a time when, in terms of economics, more women workers were employed outside the home than ever before. For Norway, this was a very important schematic and structural societal change.

1163 Øivind Larsen, "Doctors, Migration, and Professional Career" in Øivind Larsen and Bent Olav Olsen (eds.) The Shaping of a Profession: Physicians in Norway, Past and Present (Canton, Massachusetts: Science History Publications, 1996), 454. 
While medical institutions had been becoming more egalitarian throughout the time period between 1934 and 1978, the institutional Norwegian Church had tried to sidestep the issue of women becoming priests. However, debate on the issuedid not stop. As well, there was a noticeable decline in participation in routine church activities. As Ingrid Bjerkås (1901-1980), the first woman to be ordained in Norway in 1961, so succinctly noted, the Church seemed to be acting in a comfortable isolation."Behind [their resistance to the idea of women priests] is an isolated churchunfortunately more concerned about its self importance and with [a type of] language that people barely understand." 1164 Her appraisal of the situation was that, "on the ground", people were not against the idea of women priests. The idea had not, however, received validation within the institution itself to the extent that some worried about the ERA as mandating acceptance of women as priests. ${ }^{1165}$ But institutional change within DNK was not far off and that institution would eventually accept women as priests, indeed as bishops. That institution would not only change to the extent that gender equality extended into the sacristy but that DNK's position on sexuality would be rewritten within the next twenty five years. Persons, who were in committed homosexual relationships, would by 2008, be accepted as priests in DNK. ${ }^{1166}$

In the last quarter of the twentieth century one might have expected the last vestiges of Victorian sexuality to be laid to rest. Women's sexuality had been medicalized during that period in many forms; one way was to portray women as "hysterical." Yet, after all that time, in 1977, a book by Otto Weininger (1880-1903) was translated to Norwegian by Sven Kærup Bjørneboe (b. 1943) and was reviewed by Carl Fredrik Engelstad (1915-1996) in not one, but two articles for Aftenposten. ${ }^{1167}$ In 1903, Weininger, an Austrian philosopher, published his main work, Sex and Character, in which he set out his thoughts on "the woman problem" among other things. ${ }^{1168}$ Another consistent theme in Weininger's works is the idea of willing oneself a genius, aided by embracing celibacy. The book is often characterized as misogynist and anti-Semitic but there were some who still praised it. ${ }^{1169}$ That Weininger remained an idol with regard to the "woman problem" and that, 75 years after his death, in the midst of agitation for gender equality, that his book should be re-issued is an indication of how strong patriarchal attitudes were. It was also an indication that these ideas are conveniently

1164 Arbeiderbladet, January 14, 1978, 16.

1165 Aftenposten (a.m. Edition), January 16, 1978, 23. In January, a secretary for the Consumer and Administrative Cabinet Minister, Bjørg Leite, had said that the women priest question was a "borderline" case and that, as the proposal was then written, there would be an exception of the beliefs of a faith community. However, this did not materialize in the law that was actually passed.

1166 Rosemarie Köhn was the first female bishop in DNK; Per Lønning ordained her in 1969.

1167 Aftenposten (a.m. Edition), February 6, 1978, 5.

1168 Ibid. "Geschlecht und Charakter" The phrase "the women problem" is from a comment by August Strindberg on Weininger's book.

1169 The Nazis used it in their propaganda. 
re-cycled form time to time, often with the same type of political proponent and used for the same purpose. ${ }^{1170}$

Various models exist concerning institutional change over time. On such model is that of Stephen Krasner called "punctuated equilibrium." This enjoys "widespread acceptance among institutionalists" "1171 and theorizes that institutions enjoy a long period of stability which are then, from time to time, “'punctuated' by crises that that bring about relatively abrupt institutional change, after which institutional status again sets in." 1172 The problem with this model, is that,institutions explain everything until they explain nothing. Institutions are an independent variable and explain political outcomes in periods of stability, but when they break down, they become the dependent variable, whose shape is determined by the political conflicts that such institutional breakdown unleashes. Put somewhat differently, at the moment of institutional breakdown, the logic of the arguments is reversed from "Institutions shape politics" to "politics shape institutions."1173

As Thelen and Steinmo acknowledge, a "more dynamic model is needed to capture the interplay of the two variables over time." 1174 I believe that the dynamism that is needed to explain not only the two variables these editors mention but additional variables is the co-productionist idiom model that I have been using throughout this work. I also agree that the assumption that "institutions explain everything" is a limiting factor in light of how the Jasanoff model works at all levels of society. Granted, to look at all four fields - institutions, discourses, representations and identities - adds more "stickiness" than some researchers might like. But, as a tool for a comprehensive understanding of social change, I think that "stickiness" is well worth the effort.

Despite the fact that the Krasner "punctuated equilibrium" model has been criticized, the idea does fit well with the Pescosolido model that was mentioned in earlier chapters. But the idea of "stickiness", in which normative change factors are intertwinedat all levels works against the idea of any "pure" or "neat" Weberian types ${ }^{1175}$ and toward the Tamanaha and the Tuori model for legal norm formation.

1170 Aftenposten (a.m. Edition), February 6, 1978, 6. The book reviewer was a well-known author, journalist and Director of the Norwegian National Theater in 1960-1961. To be fair,along with Englestad's second of two articles, another book review was printed and this was of Sissel Lange-Nielsen's book entitled Hysteria or Sickness: On Women and Psychiatric Problems published by Pax in 1977.

1171 Kathleen Thelen, Sven Steinmo, and Frank Lonstreth (eds.), Structuring Politics (Cambridge: Cambridge University Press, 1992), p. 15. Please see Stephen Krasner, “Approaches to the State: Alternative Conceptions and Historical Dynamics" in Comparative Politics, 16 (1984): 223-246.

1172 Ibid.

1173 Ibid.

1174 Ibid.

1175 Although Weber never meant for the "pure" type to be anything other than an abstract conception, it is usually used as leading to an existing reality. 
To an extent, the four Jasanoff categories of institutions, discourses, representations and identities are "sticky" factors. They can and often do overlap and the discourse of "woman is worker" is one example of this overlap. In Norway at this time this discourse was particularly salient. For example, an editorial in Aftenposten explicitly discussed the essence of "womanhood" and implicitly, the nature of "feminism” when Nina Britt Berge's editorial entitled "Women's rights - quo vadis?” was published in early April. ${ }^{1176}$ Berge found it "astonishing" that many women were of the opinion that they represented values other than those possessed by men, the "so-called meek values." Citing to statements by Kaya Irgen and Ingeborg Moræus Hanssen, Berge agreed that it may well have been that the essence of womanhood was different from the essence of male culture. But, for her, "the aim of real equality must be for men to go back to the home and for women in large numbers to go out into the world and make salaries." ${ }^{1177}$ And, as noted above, this was what was happening in Norway.

Motherhood can also be seen as an identity, a discourse - even as a representation and institution. What is evidence of one category can and does reinforce other categories. For example, at Easter time, 1978, several articles in Aftenposten focused on the role of parents in the lives of children. These children said approximately what social researchers would only confirm later, through various methodological machinations. On the role of woman as cleaner, children wrote such things as "A mother is someone who washes [house/clothes/us]", "Momma washes dishes" and "Momma cleans up - pappa messes things up." When comparing roles in the family, children said, for example, "A mother must do everything - Pappa is good at repairing things." As to temperament, one wrote, "Momma is patient, pappa gets angry quicker." Finally, the role of women in the home was summarized, as "Momma doesn't have any time." 1178 The "patience" of women who were not only mothers but also workers is a classic representation of these meeker values but they also served to reinforce various political models of the institution of motherhood.

The idea that a women's place was primarily or only in the home yielded at this time to the idea that women themselves would decide whether or not to bear children, whether or not to work outside the home and whether or not to be married. As a clue to how institutional politics were affected by these changes, we find that Conservative Party women went on the political offensive in mid-March 1978, looking toward immigrant women for increased membership. With some chagrin, Eva Bull Lund reported that they had "missed a great deal" in not reaching out to immigrant women before. Lund went so far as to appeal to Pakistani families to "not try to become like us"

1176 Aftenposten (a.m. Edition), April 5, 1978, 6.

1177 Ibid.

1178 Aftenposten (a.m. Edition), March 22, 1978, 34. 
but to "hold onto their family traditions and their culture."1179 The political calculus involved in this statement seemed to be that, rather than take a position against immigrants, as one might expect Conservative Party members to do, immigrants would be welcome, as long as these immigrants held onto their own patriarchal traditions and culture. The goal was to keep women's status as it had been at any cost, even if this meant reaching out to various, non-white ethnic immigrant groups.

1179 Aftenposten (p.m. Edition), March 7, 1978, 4. 